\title{
On the Banks of the Tiber: Opportunity and Transformation in Early Rome*
}

\author{
ANDREA L. BROCK, LAURA MOTTA AND NICOLA TERRENATO
}

\section{ABSTRACT}

A geoarchaeological coring survey of the Forum Boarium has shed considerable light on Rome's archaic landscape. We present the first empirical evidence that substantiates ancient and modern assumptions about the existence of a river harbour and ford in early Rome. Prior to the growth of the city, the riverbank - reconstructed as a high ledge at the base of the Capitoline Hill and a low-lying shore north of the Aventine was particularly advantageous for river-related activities. However, the river valley changed significantly in the sixth century B.C.E., as a result of complex fluvial processes that were arguably spurred by urbanisation. Around the beginning of the Republic, Rome's original harbour silted up, and a high, wide riverbank emerged in its place. The siltation continued until the Forum Boarium was urbanised in the mid-Republic. In order to build their city and maintain river harbour operations, the Romans therefore had to adapt to dynamic ecological conditions.

Keywords: Archaic Rome; environmental archaeology; coring survey; fluvial landscapes; historiography; urbanisation; human-environment interactions

The existence of a river harbour and ford in the lowland between the Capitoline and Aventine Hills is an entrenched assumption in the scholarship on Rome's origins, reflecting what are thought to be the natural advantages of the site, positioned at a crossroads in prehistoric central Italy. ${ }^{\mathrm{I}}$ It is thought that early seafaring ships, which

\footnotetext{
* The Forum Boarium coring survey was promoted by the Sovrintendenza ai Beni Culturali di Roma Capitale. Funds for the research were generously provided by the Loeb Classical Library Foundation, Gerda Henkel Foundation, American Philosophical Society, Etruscan Foundation, Fondazione Lemmermann, University of Michigan and University of St Andrews. Coring survey requires cross-disciplinary collaboration, and we were fortunate to have at various stages of this work consultation with geologists and environmental scientists from the Istituto Nazionale di Geofisica e Vulcanologia in Rome and a number of academic institutions; we especially acknowledge the contributions made by Fabrizio Marra, Laura Sadori, Jan Sevink, Cristiano Nicosia, Fabio Florindo and Patrizia Macrì. Albert Ammerman consulted on the coring strategy in the field in 20I3-I4. We remain grateful for the support of Monica Ceci. Daniel Diffendale provided essential topographic and graphic expertise. Mattia D'Acri and Laura Banducci kindly assessed the ceramic assemblage from the cores. The fieldwork would not have been possible without our student assistants. The lead author wrote this article while supported by an Early Career Fellowship from the Leverhulme Trust. Zachary Hallock, Myles Lavan, Christopher Smith and Elizabeth Wolfram Thill each offered valuable input on drafts of this article. We are also grateful for the helpful comments provided by the anonymous reviewers.

1 A 'harbour' is defined as a feature of the natural landscape that provides a berthing or landing for boats; a 'port', in contrast, refers to man-made infrastructure. A 'ford' is a natural landscape that permits relatively safe river-crossings by wading or driving through water that is slow and/or sufficiently shallow.
}

JRS III (202I), pp. I-30. (C) The Author(s), $202 I$.

Published by Cambridge University Press on behalf of The Society for the Promotion of Roman Studies. This is an Open Access article, distributed under the terms of the Creative Commons Attribution licence (bttp://creative commons.org/licenses/by/4.o/), which permits unrestricted re-use, distribution, and reproduction in any medium, provided the original work is properly cited.

doi:IO.IOI7/SOO75435821000344 


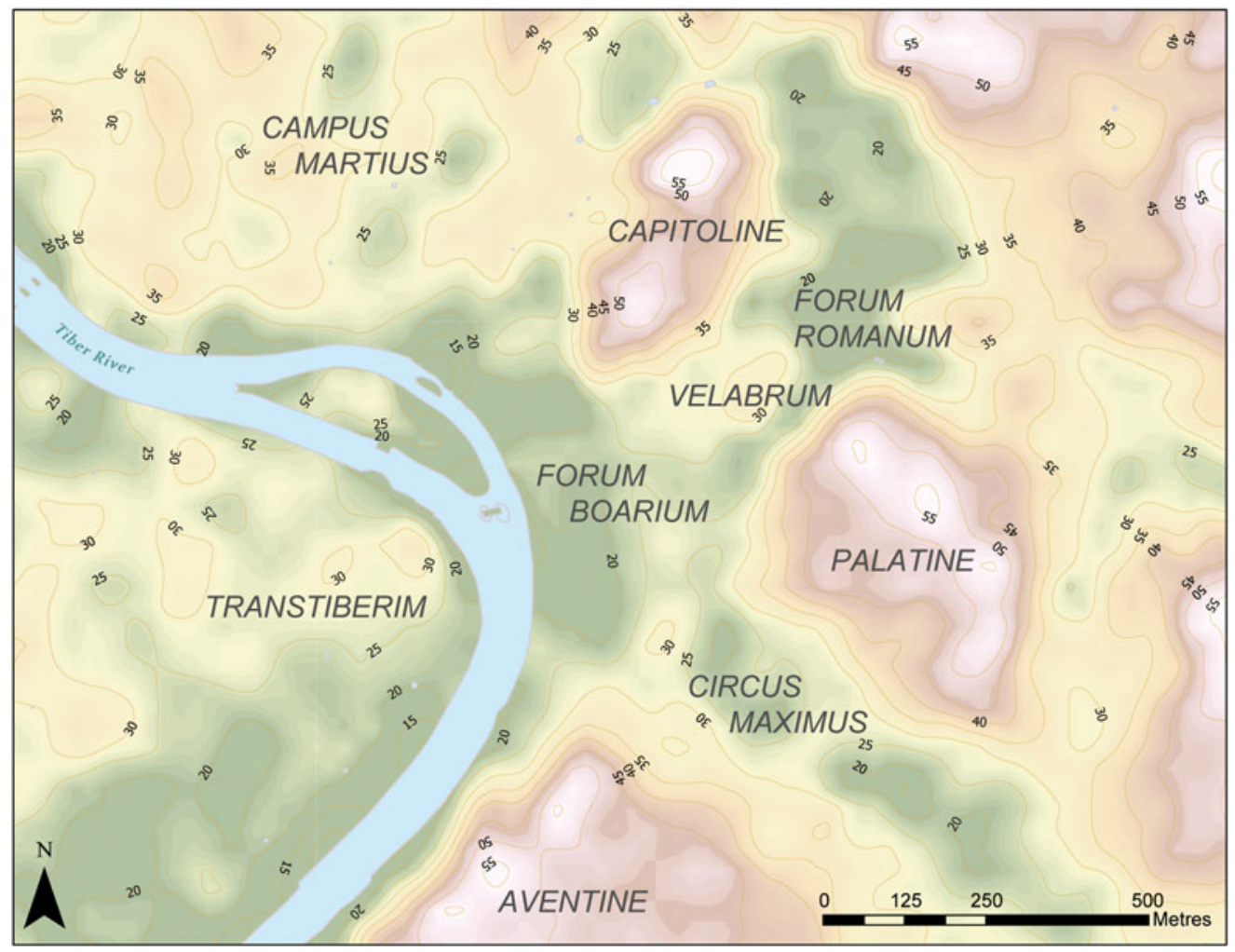

FIG. I. Topographic map of modern Rome with the ancient names of regions of the city. (Andrea L. Brock)

would have found a dearth of suitable harbours on the Tyrrhenian coast of Latium, could sail into the mouth of the largest river in central Italy, the Tiber, and travel fifteen miles upstream. On the east bank just south of the Tiber island - a district that came to be known as the Forum Boarium (Fig. I) - sailors would find a convenient landing place. Similarly, overland travel north-south between Etruria and Campania and east-west between the inland mountains and coast would find a hospitable crossing point, either by ford or ferry, at this particular river bend. These topographic circumstances would have had significant implications for the growth of a city at a site seemingly poised for pan-Mediterranean trade and regional dominance. Long before all roads led to Rome, the Forum Boarium valley would have been a major thoroughfare for people and goods moving around central Italy. ${ }^{2}$

This common conception of early Rome has its roots in the ancient literary record and has manifested itself in various forms in scholarship since the nineteenth century (below, Section I), but is in fact based on extremely limited direct evidence. Archaeological levels associated with Rome's prehistoric riverine activity are situated over $10 \mathrm{~m}$ below the modern surface, severely impeding research in the river valley. However, environmental approaches are beginning to offer a productive avenue to early Rome by revealing previously unknown topographical and ecological details. Recent geoarchaeological

\footnotetext{
2 Although we use here the 'Forum Boarium valley' as a convenient label for the area between the Capitoline and Aventine Hills, geomorphologically this is actually a confluence of three distinct valleys: the Tiber river valley, the Velabrum (the valley between the Capitoline and Palatine Hills) and the Vallis Murcia (the valley between the Palatine and Aventine Hills).
} 
investigations - a deep coring survey carried out in the Forum Boarium between 20I 3 and 2019 - have shed substantial light on Rome's central riverbank as it existed before and changed alongside urban growth at the site.

After reviewing the state of knowledge of early activity in Rome's river valley and introducing the Forum Boarium Project, this paper makes two major advances. First, we present a new reconstruction of Rome's riverine landscape in the early sixth century B.C.E. In doing so, we provide the first empirical evidence to suggest that the particular topographic and hydrological conditions in the valley between the Capitoline and Aventine Hills would in fact have facilitated harbour and fording activity in this early period. Although we can now re-evaluate with greater certainty and in finer detail the advantages offered by Rome's natural landscape, the geoarchaeological record also makes clear that this was not a static, stable setting. Thus the second major contribution of this paper is to offer new evidence for landscape transformation, as the Tiber shifted and the river valley silted up between the sixth and third centuries B.C.E. The district of the Forum Boarium in the historical period was the product of centuries of fluvial change, followed by urbanisation of the floodplain from the mid-Republic onwards. By tracing the evolution of Rome's riverbank, it ultimately becomes clear that the mutability of the landscape compelled inhabitants to adapt their river-related activities both rapidly over a period of a few generations and progressively over the centuries.

\section{PREVIOUS CONCEPTIONS OF ROME'S EARLY RIVER VALLEY}

\section{Velabrum Swamp}

Ancient authors demonstrate a general awareness or assumption that the Tiber river was important for the city's early development. ${ }^{3}$ The first modern generation of Roman historians similarly emphasised Rome's strategic position along trade routes within central Italy, and the Mediterranean more broadly, as integral to the city's early success. These perceived economic opportunities relied heavily on the presumption, drawn from ancient written sources, that Rome controlled a seaport at the mouth of the Tiber from the regal period. ${ }^{4}$ We can understand how both ancient and modern writers interested in the city's origins believed the early incorporation of Ostia to have been an absolute necessity, especially considering the ostensibly challenging landscape at the site of Rome itself. 5 Several ancient sources refer to a swamp that originally existed in the Velabrum (the valley between the Capitoline and Palatine Hills that stretches to the Tiber) and the need to use a ferry to travel between the Aventine Hill and the rest of the city. ${ }^{6}$ This body of water at the margins of the Tiber, so the story goes, existed until the construction of the Cloaca Maxima, the city's first drainage channel. ${ }^{7}$

Practically speaking, the marshy landscape envisaged by both ancient and modern authors would not have been conducive for harbour activity or foot traffic. For this reason, Joël Le Gall, in the first comprehensive survey of the Tiber's history, argued that

3 Cic., De re pub. 2.Io-I I; Livy 5.54.3-4; Dion. Hal., Ant. Rom. $3 \cdot 44$.

4 Niebuhr I 828: 302-3; Mommsen I 854-6: I, 44-8; Beloch I926: I 58, 200-I. The legendary fourth king of Rome, Ancus Marcius, was credited with extending Roman territory all the way to the coast and setting up salt works at Ostia (Liv. I.33.9; Dion. Hal., Ant. Rom. 3.44; Plin., HN 3 1.89).

5 Niebuhr I828: 247-8, 308-9, 336; Mommsen I854-6: I, 44-5, 99-I00; Dyer I857: 721, 8I 2-I3; Beloch I926: 202.

${ }^{6}$ Var., Ling. 5.43-4, 5.I49; Ov., Fast. 6.40I-I4; Prop. 4.9.5; Tib. 2.5.33-4; Liv. I.I 2.Io. Plutarch (Rom. 5.5) offered a similar anecdote but with the insightful caveat that such a ferry was necessary when the Tiber flooded over its banks.

7 An early infrastructural project credited to Tarquinius Priscus and/or Tarquinius Superbus (Liv. I.3 8.6, I.56.2; Dion. Hal., Ant. Rom. 3.67.5, 4.44.I; Plin., HN 36.106-8). 
the Forum Boarium was in fact a poor choice for Rome's primitive harbour. ${ }^{8}$ According to this conception of Rome's original landscape, the lowland would require human intervention - drainage, land reclamation and the creation of a river embankment before the river valley could have been useful to the city's early inhabitants.

Given that the ancient sources were written several centuries after the period they purport to memorialise, these accounts of Rome in the seventh and sixth centuries B.C.E. are extremely dubious. The literary record mirrors the authors' contemporary society in various ways, and ecological conditions had changed significantly by the time the first 'histories' of early Rome were composed in the third century B.C.E. ${ }^{9}$ As one of the largest cities of the pre-modern world, Rome in the historical era relied on extensive commercial port infrastructure along both riverbanks to support heavy traffic on and around the river, in addition to seaports at Puteoli on the Bay of Naples and at Ostia. ${ }^{\text {IO }}$ The riverine landscape familiar to ancient authors must therefore have been morphologically, topographically and functionally different from the prehistoric setting. Moreover, a robust documentary record makes it clear that floods of the Tiber periodically inundated the city's lowlands. ${ }^{\text {I }}$ This recurrent hydrological challenge may explain why ancient authors imagined the city's deep past as characterised by a swampy landscape that required drainage. Nonetheless, despite the inherent problems with the literary record, modern scholars continued to presume the existence of a swamp in regal Rome for many decades, until recent geoarchaeological research dispelled it (below, Section III). ${ }^{\mathrm{I} 2}$

\section{River Harbour}

Alongside the image of a swamp in the area of the Velabrum, there is also a separate conception, which emerges in both mythical and quasi-historical accounts from the later literary record, that boats were able to land at the shore of Rome in the prehistoric era. Most famously, at a climactic moment in Book VIII of the Aeneid, Vergil described how the itinerant Trojans first came to Rome. Guided by the god Tiberinus, Aeneas and his crew rowed their boats up the river to Evander's settlement on the Palatine, where they came ashore in the vicinity of a precinct sacred to Hercules. ${ }^{\mathrm{I}}{ }^{3}$ We can link this story with the Forum Boarium, where four distinct sanctuaries, including the Ara Maxima, commemorated the region's associations with Hercules. ${ }^{\text {I4 }}$ Furthermore, Dionysius of Halicarnassus described how in the mid-fifth century a Sabine army 'sailed down the Tiber river and landed at that part of Rome where the Capitolium stands not a full stade away from the river'. ${ }^{15}$ This account may be a reference to the stretch of riverbank in the area of the Forum Boarium, or potentially to the southern edge of the Campus Martius.

By the time these accounts of an early harbour were written in the Augustan era, it is clear that the Forum Boarium district was closely associated with port activity. The first corroborating evidence for the existence of a historical port was provided by the burgeoning sub-discipline of topography in the nineteenth century. For Roman

8 Le Gall I953: 93-5, I Io.

9 On the limitations of the literary record on early Rome, see Wiseman I996; 2008.

10 Keay 20I 2; Tuck 20I3. E.g. Pliny $\left(H_{3} 3 \cdot 53-5\right)$ described the abundant activity on and around the Tiber in the first century C.E.

11 Aldrete 2007.

12 See Ammerman and Filippi 2004 and Ammerman 2006 for a more comprehensive historiography of Rome's swamp.

13 Aen. 8.28-I 25; Secci 2013. Cf. Ovid's account of Evander arriving at the Palatine by boat (Fast. I.539).

14 Ziółkowski I992: 46-50; Torelli 2006.

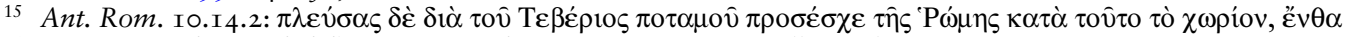

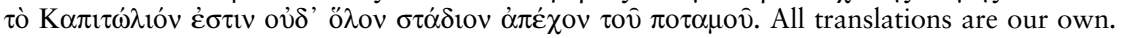


topographers striving to map the ancient city, a short passage from Varro (Ling. 6.I9) became a significant crux. In a reference to the Portunalia festival, Varro mentioned the presence - at least in the first century B.C.E. - of a shrine of Portunus, the god of ports, at the Portus Tiberinus. ${ }^{16}$ The Fasti further indicate that the Portunalia took place near the Pons Aemilius. ${ }^{17}$ Based on these references and his reading of the Notitia, a topographic survey of Rome in the fourth century C.E., Christian Hülsen originally identified the Temple of Portunus with the Round Temple of the Forum Boarium. ${ }^{\text {I8 }}$ André Piganiol preferred to attribute the nearby Ionic temple to Portunus, and drew further inferences from the supposed proximity of republican port installations mentioned by Livy. ${ }^{\text {I9 }}$ In these ways, the first generation of Roman topographers closely tied the Forum Boarium and Temple of Portunus to a commercial port that existed at least from the late Republic.

These topographical inferences received archaeological corroboration from discoveries made during Fascist efforts to renew Rome, when huge swathes of the city were stripped of their medieval and early modern structures. Excavations prior to the construction of the Palazzo dell'Anagrafe revealed the first physical traces of port infrastructure in the Forum Boarium: Trajanic storage facilities (borrea). ${ }^{20}$ Even more momentous findings were made nearby, after demolition around the Church of Sant'Omobono revealed an ancient sanctuary complex. ${ }^{2 \mathrm{I}}$ In I937-8, Antonio M. Colini led the first excavations of the area, unearthing at great depth a scintillating collection of prehistoric materials. Discoveries included the stone podium of a very early temple building, which had been adorned with an archaic terracotta statue group of Hercules and Minerva, currently on display at the Musei Capitolini. Excavations also produced an impressive ceramic assemblage of Bronze Age, imported Greek, and Early Iron Age Etruscan wares, found mixed in secondary contexts at the Sant'Omobono sanctuary. ${ }^{22}$

Drawing on these archaeological discoveries, mid-twentieth-century scholars began writing of a commercial port that stretched back to the prehistoric era. ${ }^{23}$ The presence of orientalising Greek pottery, in particular, led to the conclusion that foreign trade via Rome's harbour began already in the eighth century. ${ }^{24}$ Colini located the harbour in the vicinity of the Anagrafe building, envisioning a low bank that allowed access for boats, which was eventually covered by later port infrastructure. ${ }^{25}$ Over the decades, many scholars have accepted and echoed such inferences about an early harbour in the Forum Boarium, with few sceptics or dissenters. ${ }^{26}$ Some further posited that the first major

16 Ling. 6.I9: 'Portunalia dicta a Portuno, cui eo die aedes in portu Tiberino facta et feriae institutae.' For Portunus as god of ports as well as or instead of the god of gates, see Cic., De nat. deo. 2.66; Verg., Aen. 5.24I-3; Ov., Fast. 6.54I-50; Apul., Met. 4.3 I.

${ }_{17} \mathrm{CIL} \mathrm{I}^{2}$ p. 325 ; the Fasti Vallenses: 'Portuno [a]d pontem Aemilii'; the Fasti Allifani and Amiternini: 'Portuno ad pontem Aemilium'.

18 In Region XI, Circus Maximus, of the Notitia, Hülsen (I 896: 262-3) read 'Portunium' between the 'Velabrum' and 'arcum divi Constantini'.

19 Piganiol I909, drawing on Livy 35.IO.I2, 40.5 I.4-6, 4 I.27.8. This remains the current attribution: the Ionic temple across from the Casa dei Crescenzi is considered to be the Temple of Portunus, whereas the Round Temple is typically associated with Hercules Olivarius or Hercules Victor.

20 Colini et al. I986.

21 We refer to this archaeological zone generally as the Sant'Omobono sanctuary. Two particular phases of the site are discussed: the early archaic river-harbour temple, and the early republican sanctuary, consisting of twin temples seated atop a high platform.

22 See Terrenato et al. $20 \mathrm{I} 2$ and Brocato and Terrenato 2013 for a comprehensive re-assessment of the early excavations at Sant'Omobono and full bibliography of previous publications.

23 Cressedi I949-5I: 53; Le Gall I953: 93-9; Gjerstad I966: 30, 43; Coarelli I968; I977: 823.

24 Colini I980; Coarelli I988a: 23-5, II 3-27; I988b; Filippi 2005: 99-ı0I; Domínguez Pérez 2006 : I83.

25 Colini I980; Colini et al. I986.

26 Accepted by Coarelli I988a: 23-5, II3-27; I988b; Torelli I990: 48-5I; Grandazzi I99I: I24; Holloway I994: 90; Coarelli I995; Cornell I995: 48, I 2 ; Carandini I997: 284-5, 523-30; Buzzetti I999; Filippi 2005: 99-IOI; Domínguez Pérez 2006: I83; Torelli 2006: 574-5; Coarelli 2007: 307-I 5; Keay 20I2: 34-6; Tuck 20I3: 327-8; Fulminante 20I4: 93; Hopkins 20I6: 6I-2; Lomas 20I8: I46; Bradley 2020: I39; Cifani 202I: 


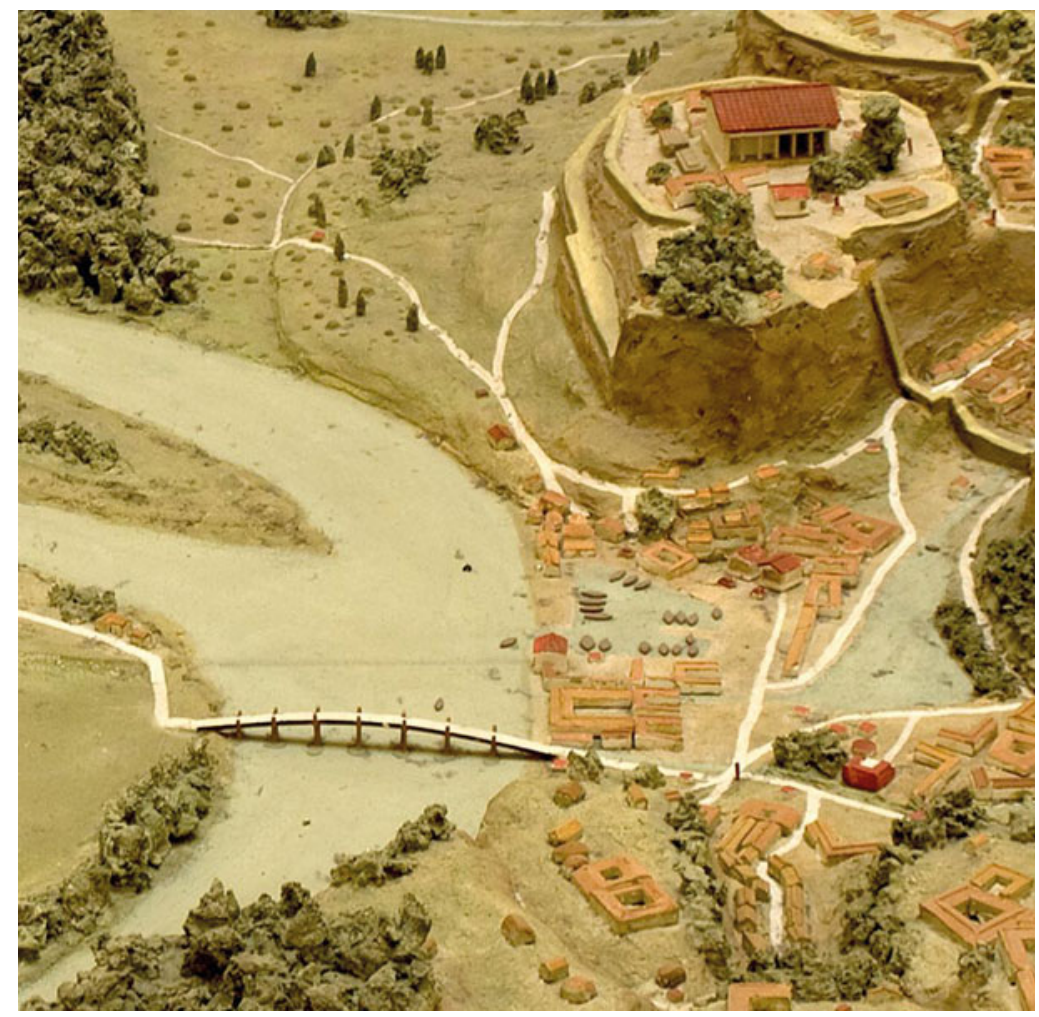

FIG. 2. Detail of Lorenzo Quilici's plastic model of archaic Rome, showing his reconstruction of the Portus Tiberinus in the region of the Forum Boarium. (Photograph: Andrea L. Brock)

investment in commercial port infrastructure at the Portus Tiberinus should be associated with the archaic temple building at Sant'Omobono and dated to the reign of Servius Tullius. ${ }^{27}$ Although the sources do credit Servius with building a temple in the Forum Boarium, there is no mention of contemporary port infrastructure. ${ }^{28}$ This conception of an early Portus Tiberinus manifests itself in a particularly imaginative form in Lorenzo Quilici's plastic model of the archaic city. ${ }^{29}$ Built in 1990 for 'La Grande Roma dei Tarquini' exhibition and put on display at the Museo della Civiltà Romana, the model depicts a densely urbanised riverbank district, complete with permanent quays and docks set back from the river (Fig. 2). Quilici's visualisation is evocative but

I 45-52. Holland (I96I: I93-9) envisioned a landing in the area of the Forum Holitorium for boats coming from upstream. Heurgon (I973: 55 I) questioned the extent of Rome's maritime ambitions until the late fourth century. Giovannini (I985: $38 \mathrm{I}-2$ ) argued that Rome was badly placed for maritime trade and that the Tiber was not navigable for merchant ships. Smith (I996: I79-8I) took a measured approach, rightly noting the lack of categorical proof of an early port. Ammerman and Filippi (2004: I7 n. 37) dismissed the possibility of an archaic harbour, although their presumption was arguably based on faulty inferences drawn from inadequate coring data (see further below).

27 Pisani Sartorio I989: I6-I7; Coarelli I995; 2007: 308; Bianchi 2020.

28 According to Dionysius (Ant. Rom. 4.27.7), this was a temple to Fortuna. Livy (5.I9.6) mentioned that Servius Tullius founded a temple of Mater Matuta, although does not specifically state that this was in the Forum Boarium. Ovid (Fast. 6.477-80, 6.569-7I) claimed that Servius Tullius was associated with temples of both Fortuna and Mater Matuta in the Forum Boarium. See Miano 2018: 77-98 on the archaic cults in the Forum Boarium.

29 Cristofani I990; Quilici I995. 
problematic, not only because it is based on little material or textual evidence, but also because it fails to account for some basic hydrological issues, such as seasonal flooding.

\section{Ford across the Tiber}

In their seminal work of I929, A Topographical Dictionary of Ancient Rome, Samuel B. Platner and Thomas Ashby conceived of Rome's lowland landscape much like their contemporaries: the Velabrum valley was thought to have originally been marshy, before the area was drained by the Cloaca Maxima and the riverbank eventually built up as part of the Portus Tiberinus and Temple of Portunus. ${ }^{3 \circ}$ However, Platner and Ashby also made a further bold assumption that would go on to become ingrained in the collective scholarly mind: "The importance of the site of the Palatine and of Rome is mainly due to its command of the crossing of the Tiber just below the island, which must be of great antiquity, and was probably the only one in the whole lower course of the river.' ${ }^{3}$

Indications of such a ford lie less in the ancient literary record than in Platner and Ashby's reading of Rome's urban topography. Although the myth of Hercules' arrival at Rome includes an account of the hero shepherding his cattle across the Tiber, other clear indications of a ford at Rome are absent from the ancient literary record. ${ }^{32}$ Dionysius, an Augustan-era historian of early Rome, outright rejected the notion that it was once possible to cross the river on foot. ${ }^{33}$ This remark reflects his contemporary conditions: in the historical period, as today, the Tiber was typically not fordable at Rome. For Platner and Ashby, however, the location of the Pons Sublicius (Rome's oldest bridge) and the route of the Vicus Iugarius (one of Rome's oldest roads) indicated the presence of a ford at a point of slack water downstream from the Tiber island. ${ }^{34}$ They further linked their conceptions of a river-crossing to the early exploitation of salt beds on the right bank at the mouth of the Tiber and transport along the Via Salaria through the Forum Boarium. ${ }^{35}$

Like Platner and Ashby, many scholars have emphasised the antiquity of the salt trade and re-asserted the notion that there originally existed a ford, ferry, or generic crossing-point of the Tiber at Rome. ${ }^{36}$ In addition to inferences drawn from the topography of the later city, the supposed position of a ford is arguably bolstered by assumptions about advantageous hydrological conditions that would have also facilitated harbour activity in the Forum Boarium. Although archaeological or environmental corroboration for the ford has hitherto been lacking, the prehistoric findings on the Capitoline Hill offer some indirect support by proving the existence of a settlement from at least the late second millennium. Indeed, Alberto Cazzella, director of

\footnotetext{
30 Platner and Ashby I929: I 26-7, 430-I, 549-50.

31 Platner and Ashby I929: 536.

32 Hercules: Livy I.7.4. In other accounts of the myth (Verg., Aen. 8.20I-4; Ov., Fast. I.543-6), Hercules' cattle grazed in the river valley, although it is not specified that they had crossed the river to do so. Accounts of the annexation of the Janiculum and the construction of the Pons Sublicius (Livy I.33.6; Dion. Hal., Ant. Rom. 3.45; Plut., Num. 9.3) highlight the early importance of a river-crossing but are ambiguous on the notion of a pre-existing ford.

33 Dion. Hal., Ant. Rom. 9.68.2.

34 Platner and Ashby I929: 40I-2, 574-5.

35 Platner and Ashby I929: 567-8. Above, n. 4.

36 Ford: Cressedi I984; Coarelli I988a: 23-5, II3-27; I988b; Torelli I990: 30; Grandazzi I991: I08-24; Cornell I995: 48; Filippi 2005: 96-IOI; Forsythe 2005: 80; Carandini 2007: I7-28; Campbell 2012: 385-6; Fulminante 20I4: 68-9, IO2; Isayev 20I7: 82-4; Lomas 2018: 37; Bradley 2020: I39; Cifani 202I: 50-2, I45-6. Ferry: Holland I96I: I4I-78; Gjerstad I966: 43; Colini I980: 44; Colini et al. I986: I88; Richardson I992: I63, 320; Coarelli I995; 2007: 307-8, 37; Campbell 20I2: 21. Crossing-point: Alföldi I965: I93, 293; Momigliano I990: 64 .
} 
the Giardino Romano excavation, suggested that these Bronze Age inhabitants of the Capitoline might have had a strong interest in the nearby river ford. ${ }^{37}$

\section{FORUM BOARIUM CORING SURVEY}

In sum, there has been general consensus about the existence, if not the specific details, of a harbour and ford in early Rome. Until now, however, it has been difficult to acquire direct and contemporary evidence of such features. Secure arguments about Rome's early landscape and the precise role it played in the city's development have been elusive. Obscured by the late inception of the literary record and the inaccessibility of deeply buried archaeological levels, Rome's original riverine activity - like so much else from the prehistoric era - has long been consigned to the realm of myth, speculation, or untested hypothesis.

Systematic investigation of the river valley has only been made possible by recent advancements in technology and scientific analysis. Environmental studies have begun to augment traditional views of early Rome by providing novel datasets as well as nuanced perspectives on matters of human experience and societal development. Although the adoption of ecological methods and theories has been comparatively slow in Classical Archaeology, important groundwork was laid by Albert Ammerman, who was the first to lead sub-surface geoarchaeological surveys in Rome, beginning in the r98os. His work in the Velabrum challenged conventional conceptions of a swamp in regal Rome. He also argued that landscape modification, such as the filling of the lowland basin to establish the Forum Romanum, was a pivotal component in the creation of the city. ${ }^{38}$ The present geoarchaeological investigation along Rome's riverbank now shows how the process of urbanisation was not a straightforward progression from untamed land to drained and reclaimed cityscape: it was far more dynamic and complex.

This project began as part of a reinvestigation of the Sant'Omobono sanctuary. As there are few gaps in the republican and imperial pavements of the site sufficiently large to permit excavation, we devised a coring campaign to survey areas that could not be excavated. Coring survey can operate at various scales, but the process is essentially the same: a metal sampling bit is drilled into the ground to recover a cylindrical sediment core, which serves as a narrow but deep slice of archaeological and geological stratigraphy. In 2013-I4, we used a hand-held Cobra TT percussion drill to make eighteen boreholes across the Sant'Omobono archaeological zone. Each of these boreholes had a width of $5 \mathrm{~cm}$ and reached depths up to $8 \mathrm{~m}$ below the exposed ancient surface. In $20 \mathrm{I} 5$ and 2019, we expanded the coring campaign beyond the limits of Sant'Omobono, in order to survey the entire region of the Forum Boarium (Fig. 3). To do so, we hired geophysical contractors who operate a larger Beretta $\mathrm{T}_{4} 6$ rig, capable of drilling through hard stone and concrete. ${ }^{39}$ Each of the twenty-two mechanised boreholes made in 2015 and 2019 had a width of $8 \mathrm{~cm}$, and reached a depth of $15 \mathrm{~m}$ or more from the modern surface. ${ }^{\circ}$ In total, our investigations in the Forum Boarium resulted in a substantial amount of stratigraphic data - over 400 vertical metres with nearly roo per cent recovery in every core (a result not obtained in previous surveys of the area). ${ }^{4 \mathrm{I}}$

\footnotetext{
Cazzella 200I: 267; echoed by Fulminante 2014: 68-9, I02.

38 Ammerman I990; I998; Ammerman and Filippi 2004.

39 CNG S.r.l., managed by Marcello Martinelli, Massimo Lenoci and Maria Rita Caponi.

40 The cores from the 2015 and 2019 campaigns are labelled (38)-(59), so as to avoid confusion both with boreholes drilled during our previous survey of the Sant'Omobono sanctuary and with Ammerman's coring campaign in the Velabrum.

41 In earlier coring surveys, Ammerman et al. struggled mightily with recovery issues, particularly in areas closer to the modern river, as loose, wet sediments would drop out of the drill bit (Ammerman I998: 2I7 n. 8, n. I3;
} 


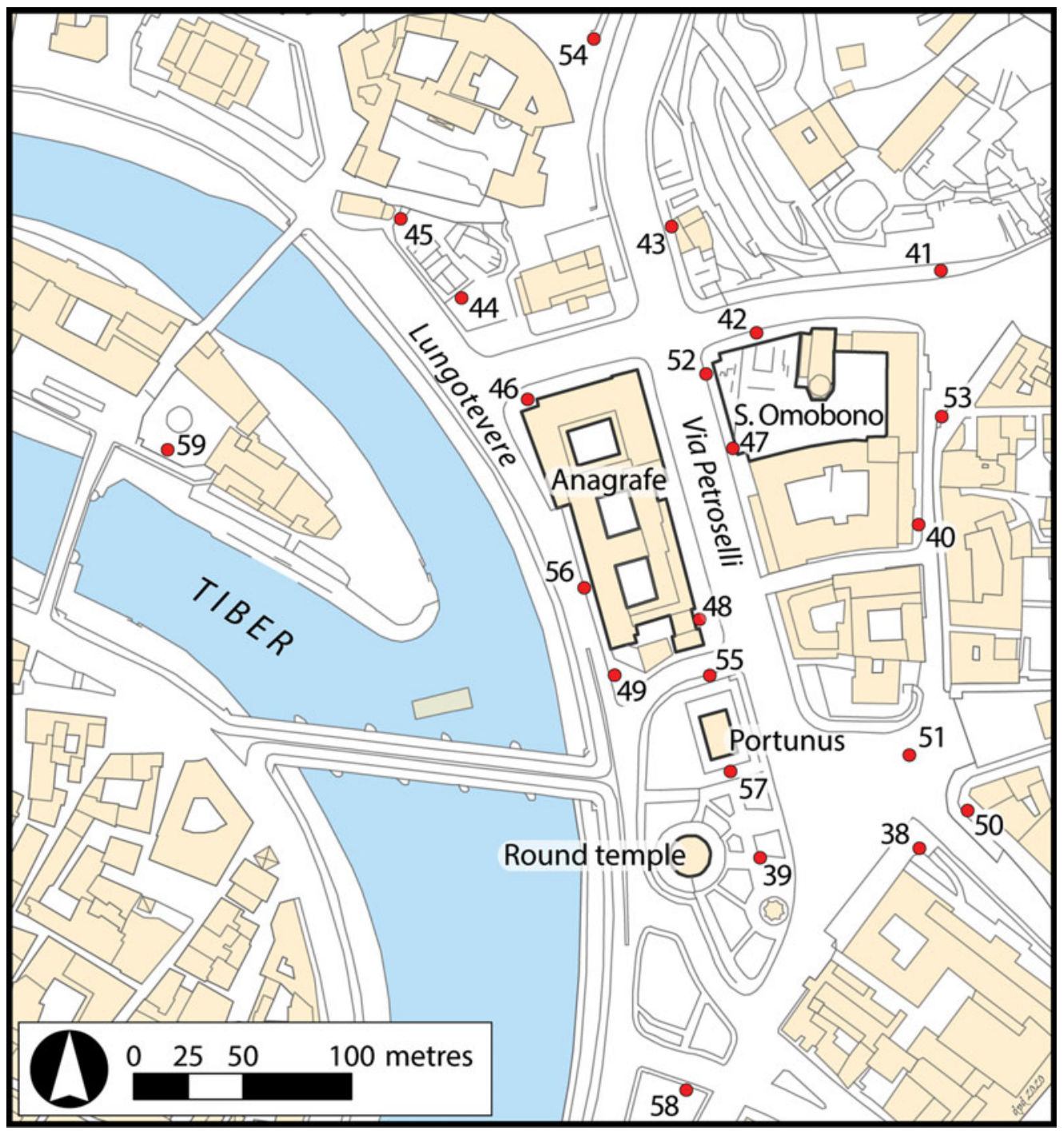

FIG. 3. Map of the modern Forum Boarium with the locations of the mechanised boreholes and relevant structures. (Daniel P. Diffendale)

After drilling the boreholes, the sediment cores were studied stratigraphically and sampled extensively. ${ }^{42}$ Alongside macro- and micro-botanical analysis, as well as granulometric and micromorphological studies, a major priority was to identify chronological markers, in order to situate the stratigraphic record in time and space. In total, we have amassed a collection of more than 200 sherds of ancient pottery and took 45 organic samples for radiocarbon dating; our chronology stretches across the

Ammerman and Filippi 2004: n. 2I; Ammerman 2006: 300). For the coring strategy and successful recovery of sediments in our project, see Brock 2016: 8 .

42 For more detailed background on the coring methodology, sampling procedures and analyses, see Brock 20I6; 20I7; 20I8; Marra et al. 2018. 
entire epoch of human settlement at Rome as well as a Holocene geological record. ${ }^{43}$ Of particular interest is the deepest anthropic inclusion (typically a ceramic sherd) in each core, as this marks a key boundary signalling human presence on the local landscape. Although Ammerman's surveys uncovered the deepest sherds at elevations around $5 \mathrm{~m}$ above the modern sea level (masl), ${ }^{44}$ our investigation revealed anthropic materials at significantly greater depths, at elevations as low as $2 \mathrm{~m}$ below sea level (mbsl). ${ }^{45}$ By documenting the low base level of the river valley, we offer a far better-defined third dimension to studies of early Rome.

\section{ROME'S RIVER VALLEY IN THE EARLY ARCHAIC PERIOD}

Excavations in other parts of Rome in recent decades have considerably increased the quantity and quality of evidence for the city's origins. A discernible shift in the archaeological record is now apparent between the late seventh and early fifth centuries B.C.E., Rome's so-called Archaic Period. While Late Bronze and Early Iron Age habitation at the site generally consisted of wattle and daub huts on the hilltops, along with small-scale terracing efforts and lowland burials, ${ }^{46}$ the sixth century saw the introduction of monumental, stone-based, and terracotta-roofed buildings. Additionally, land modification through terracing and reclamation projects helped to convert the disjointed and uneven landscape into a more level and unified setting. ${ }^{47}$ An increasing volume of archaeological evidence now shows that the sixth century was a pivotal phase on Rome's journey from hut settlement to city.

Drawing on discoveries made by the Forum Boarium Project, we offer here a new reconstruction of Rome's central river valley as it existed at the beginning of the sixth century, on the eve of this major urban development (Fig. 4). Thanks to this new and clearer picture of the topography and hydrology that once characterised Rome's landscape, in Section IV we are able to re-evaluate the range of human activity along the riverbank. Finally, in Section V we describe the substantial changes that occurred in this area from the sixth century onwards, since it is now apparent that Rome's river valley looked very different at the end of the Archaic Period than it had at the beginning.

\section{Topography}

Starting from the lowest point on the landscape, coring in the vicinity of Via Petroselli and the Lungotevere demonstrates, first, that the Tiber once flowed roughly Ioo $\mathrm{m}$ further east than its modern course and, second, that the ancient riverbed was markedly lower than

\footnotetext{
43 Many of these chronological markers have already been presented in other publications from the Forum Boarium Project (Brock 20I6; Brock and Terrenato 20I6; Brock 20I7; Marra et al. 20I8). Additional materials collected during the 2019 campaign will be included in a future publication.

44 See Ammerman I998: 2 I 5-20 and Ammerman and Filippi 2004: I4-7, n. 23, n. 37 for the deepest sherds and the 'natural land surface' in the Velabrum around 5-6 masl, with the notable exception of 2.26 masl south of the Temple of Portunus. It is unclear how a 'natural surface' was distinguished, particularly near the river. This label suggests that there exists a clear break between the geological and archaeological stratigraphy. In reality, the river valley contains a long sequence of natural alluvial deposits, some of which contain anthropic materials; it is a misnomer to try to identify a 'natural surface' in such a dynamic landscape.

45 All elevations reported by the Forum Boarium Project are based on the Sant'Omobono datum, the metal benchmark on the walkway outside the apse of the church, which has recently been re-assessed and determined to be at an elevation of 14.069 masl. On slight disparities when comparing elevations with previous archaeological campaigns, see Diffendale 2017: 7-8.

46 Cazzella 200I; Baroni 2003; Lugli and Rosa 2003; De Santis et al. 20I0. For a recent catalogue of the archaeological remains from Bronze and Iron Age Rome, see Benedetti et al. 2020.

47 For an overview of the archaeological remains from archaic Rome, see Cristofani I990; Hopkins 2016; Lulof and Smith 20I7; Ziółkowski 20I9; Filippi 2020.
} 


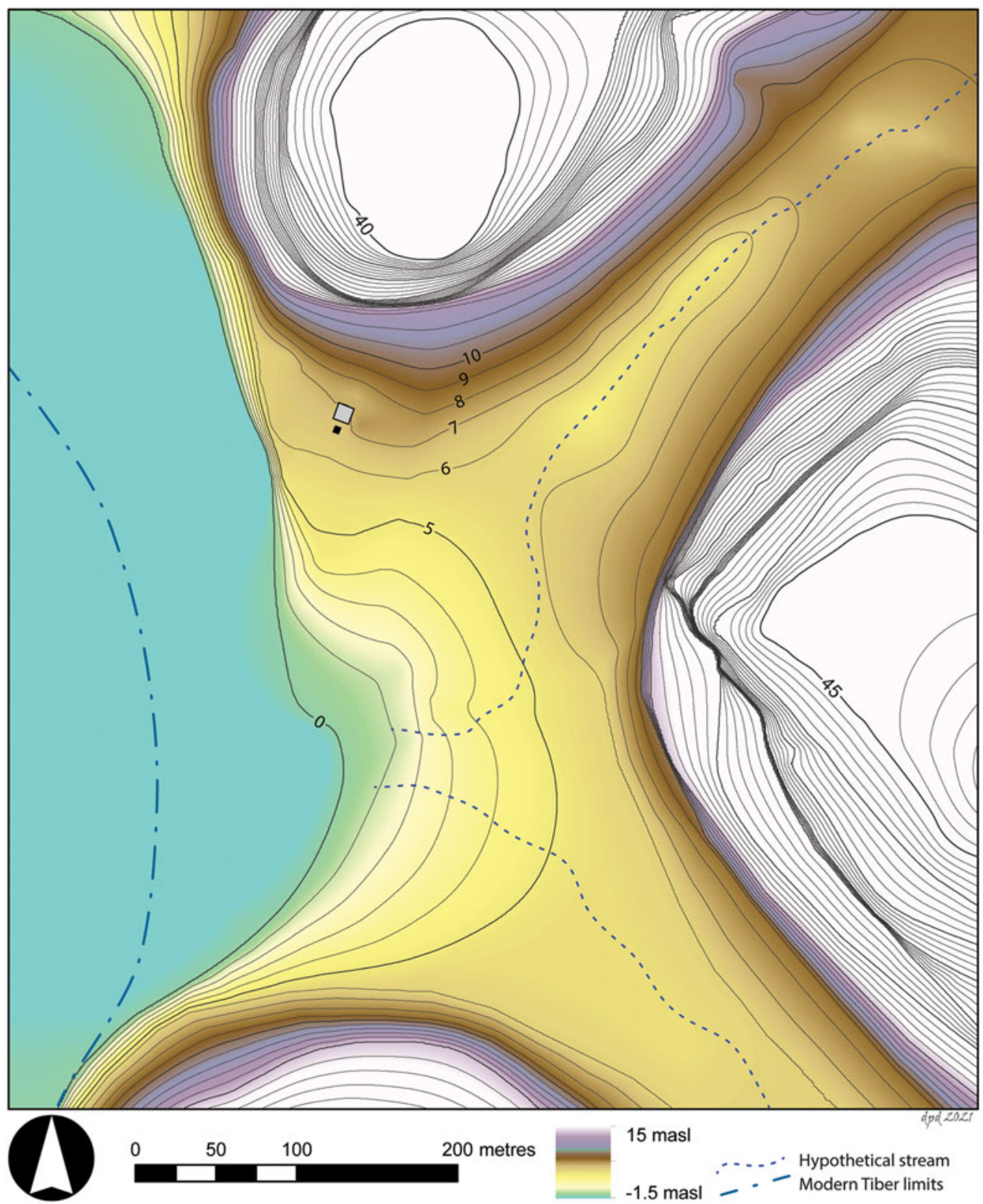

FIG. 4. Topographic reconstruction of the early archaic riverbank in the Forum Boarium, noting the position of the temple and altar from the Sant'Omobono sanctuary. (Daniel P. Diffendale)

previously appreciated. ${ }^{4}$ At elevations between roughly o masl and 2 mbsl, ten cores (39, $43,47,48,49,52,55,56,57$, and 58$)$ revealed sands and rounded gravels, interpreted as

48 The new findings support Ammerman and Filippi's conclusion about the original position of the riverbank (Ammerman and Filippi 2004: 16; Ammerman 2006: 307). 
deposits in or very near the active river channel. ${ }^{49}$ This $c$. I mbsl stratigraphic horizon contained more than twenty ceramic sherds across the cores. These pottery fragments were not found in a primary, settlement context, but in a secondary context, having been washed or dumped into the fluvial system before ultimately settling on the valley floor. Most importantly, this collection of sherds demonstrates that the Tiber river flowed in the vicinity of Via Petroselli at least until the beginning of the Archaic Period (around the beginning of the sixth century B.C.E.)..$^{\circ}$

At the margins of the Tiber, with its bed around I mbsl, boreholes have also exposed the contemporary shore. Stratigraphy from cores 38,40, 50, $5 \mathrm{I}$ and 53 is consistent with near-river environments: when rivers swell and spread over their banks, floods carry and ultimately drop fine-grain sediments as waters stagnate. The silts found in this part of the valley are typical of the low-velocity deposition in floodplain environments (periodically inundated marginal zones). These findings are, therefore, consistent with the results of Albert Ammerman and Dunia Filippi's coring survey in the Velabrum. Challenging previous assumptions about a swampy formation in regal Rome (above, Section I), Ammerman and Filippi argued that the central part of the Velabrum valley was actually seasonally dry by the time people settled at the site of Rome. ${ }^{5 \mathrm{I}}$ Our cores along the riverbank further demonstrate that the lower Velabrum valley was indeed a seasonally dry floodplain in the early centuries of the first millennium B.C.E.., not an expansive body of standing water. Impasto bruno sherds (providing a vague pre-archaic terminus post quem) were found within these floodplain sediments in core 50 at extreme depths, I masl, indicating that the terrain north of the Aventine Hill was once quite low. Given its proximity to the active river, this area must have been a recurrently submerged shore, rather than a large, permanent swamp.

In contrast to the low-lying shore in the lower Velabrum valley, a conspicuously high section of riverbank once protruded from the southern flank of the Capitoline Hill; walking beside the river from south to north, one would originally have ascended some $6 \mathrm{~m}$. Excavations and coring across the Sant'Omobono sanctuary have revealed fine-grain fluvial sediments at the base of the republican and archaic archaeological sequence. The surface sits at 7.4 masl near the Capitoline and slopes down to 6 masl along the southern limit of the Sant'Omobono sanctuary, before sloping further downwards towards the Velabrum valley. This particular zone, unlike other nearby areas, was apparently shielded from erosive forces. The existence of this elevated shelf of land may be the fortuitous product of the solid structure of the Capitoline Hill, which could well have bounded the meandering river. Coring along the western edge of the Sant'Omobono sanctuary has revealed that the ground level (at c. 6.5 masl) sloped precipitously down to the adjacent river channel (at $c$. I mbsl); this is suggestive of a steep bank created by the Tiber's erosive power. Together, these conditions indicate that in the early sixth century a prominent natural ledge was perched above the river. This

\footnotetext{
49 Several sections also had inclusions of larger, non-rounded tuff fragments, interpreted as material released from the hillslopes that ultimately settled on the valley floor; this could have been the result of quarrying activity or other urban construction. Boreholes 44, 45, 46 did not reach these depths.

50 In addition to impasto bruno sherds (which are vaguely datable to the Early Iron Age), this collection includes sherds that are more diagnostic for the Archaic Period, including examples identified as bucchero, Etrusco-Corinthian, impasto chiaro-sabbioso, impasto rosso and impasto rosso-bruno. Five samples of organic material from this stratigraphic horizon returned radiocarbon date ranges comparable to the age of the ceramic assemblage. Many of these chronological markers were collected during the 2016 season and are reported in Brock 2017; Marra et al. 2018: tab. S2. Those collected in 2019 will be presented in a future publication.

51 Ammerman I998: 219-22; I999; Ammerman and Filippi 2004; Filippi 2005; Ammerman 2006: 305-7. This seasonally dry setting contrasts with the permanently wet, swampy environment that characterised the lowland region in the sixth millennium, long before sedentary habitation at the site: Ammerman et al. 2000; Ammerman et al. 2008: IO-I2.
} 
important feature has not been recognised in previous scholarship, nor in the most recent morphological description of the Velabrum valley. ${ }^{52}$

As the low-lying shore in the southern Forum Boarium was undoubtedly subjected to regular overbank flooding, it is noteworthy that flood deposits did not accumulate and aggrade the ground level in the area closer to the Aventine, as was possible in the area at the base of the Capitoline Hill. This discontinuity should be attributed to the impact of tributary streams, one entering the Tiber from the Velabrum valley and the other from the valley between the Palatine and Aventine Hills, where the Circus Maximus would eventually evolve. Although such tributary streams no longer exist today, there are compelling circumstantial clues that they once did, including the valley morphology itself and the eventual installation of drainage infrastructure. ${ }^{53}$ These streams did not erode the land beneath Sant'Omobono, and therefore they must have entered the Tiber somewhere to the south. We have not yet determined the precise location of the creek bed. This would in any case have been ephemeral in the era before the streams were converted into canalised drains, as they would have moved across the width of their respective valleys. ${ }^{54}$ Further confirmation for the presence of tributary streams can be broadly inferred from the cores, which have revealed compositionally and granulometrically distinct fluvial sediments: often yellowish silts and sands, attributable to the Tiber river; ${ }^{55}$ and often greyish clays and silts, arguably deposited by a distinct, localised system, such as one or both of these tributaries. ${ }^{56}$ The point of confluence (probably located somewhere in the southern Forum Boarium) would have been subjected to the erosive forces of all three fluvial systems, so that the ground level remained low, particularly in contrast to the adjoining section of high, uneroded riverbank.

\section{Hydrology}

Although the sedimentary record allows us to create a topographic picture, gauging past river depth is difficult. River behaviour is influenced by a highly variable mix of hydrological inputs and outputs that change on short, medium and long timescales. However, for a site-specific reconstruction, we now have key signals that shed some light on seasonal water levels in early archaic Rome. In order to estimate the depth of the river during periods of normal or low flow, we can compare the elevation disparity between deposits within or very near the riverbed and seasonally dry marginal zones on the riverbank. The base of the Tiber's channel has been identified around I mbsl at the beginning of the sixth century, while parts of the east bank seem to have stood as low as I masl. ${ }^{57}$ Together, these data-points suggest an approximate water depth of $2 \mathrm{~m}$ or less in the vicinity of the Forum Boarium during the dry season.

In order to estimate the upper boundary of water depth, the high riverbank preserved beneath Sant'Omobono is a crucial indicator. Conveniently shielded from erosion and undisturbed by clean-up efforts, flood deposits here serve as a valuable physical record of the extent of flood waters. We can therefore be certain that floods in the

\footnotetext{
52 Bellotti 2020.

53 Ammerman I998: 22 I, Ammerman et al. 2000: I2; Ammerman and Filippi 2004: I8; Filippi 2005: IOI-2; Bellotti and Bianchi 20I9.

54 Hopkins 2007; 2012: 82-9. For the position of the creek in the Velabrum, see Bianchi 2020, although this reconstruction is incompatible with the high section of riverbank at the base of the Capitoline presented here. For the Vallis Murcia, see Carpentieri et al. 2015.

55 Ancient sources referred to the Tiber as flavus (e.g. Hor., Carm. I.2.I3, 2.3.I8; Verg., Aen. 7.30-2), an acknowledgement of the tawny colour resulting from the river's suspended sediment load.

56 These 'tributary' deposits are inferred to be sediments eroded from the local landscape, specifically the heavily reduced clays from levels associated with the Neolithic swamp which makes up the substratum of the Velabrum valley (above, n. 5I).

57 Bellotti 2020 suggests a dry-season water level at 2 masl.
} 
pre-republican era reached at least 7.4 masl, suggesting that water peaked somewhere around 8 masl, equating to a depth of roughly $9 \mathrm{~m}$. Although even higher floods are feasible, it is worth noting that any inundation cresting over 6 masl would spread into the Velabrum and Circus Maximus valleys. ${ }^{58}$ These secondary basins provided substantial accommodation space, allowing water to spread laterally before continuing to rise vertically. In other words, the volume of water necessary for a flood at Rome to swell from 6 to 8 masl would have been orders of magnitude greater than that required to push waters from 4 to 6 masl.

To summarise: prior to the late sixth-century growth of the city, Rome's river valley was the unique product of local geology and hydrological forces. It is admittedly challenging to visualise this landscape, particularly given the homogeneous terrain one experiences walking around the modern Forum Boarium. However, we should imagine a far more dramatic setting at the beginning of the sixth century. The Tiber was flowing $100 \mathrm{~m}$ to the east of its modern course, much closer to the hills of Rome. Protruding from the side of the Capitoline Hill, a conspicuous shelf once stood some $6 \mathrm{~m}$ above the surface of the adjacent river. Even during periods of heavy rain, this part of the valley would have been the last to flood and first to dry. In stark contrast, the Tiber would have overflowed first and most frequently at the low section of the channel banks due south. This area was seasonally dry, but was crossed by two tributary streams as they flowed toward the Tiber. Moving inland from this low shore, the ground level ascended gradually into the Velabrum and Circus Maximus valleys.

\section{ROME'S ORIGINAL RIVER HARBOUR AND FORD}

\section{Early Riverbank Activities}

As we have seen, coring survey has revealed key details of Rome's river valley, indicating that the Forum Boarium was once characterised by a low-lying shore (around I masl) adjoining a high riverbank (around $6.5 \mathrm{masl}$ ) at the base of the Capitoline Hill. This setting would be particularly advantageous for river-related pursuits. Although the prehistoric activities in the river valley left few material traces, we can extrapolate from the environmental reconstruction in order to make some logical deductions.

First, this low-lying shore would have been an ideal location for animals to drink at the river. Indeed, ancient sources and generations of modern scholars have made etymological inferences about the origins of the Forum Boarium as a 'Cattle Market'. ${ }^{59}$ Livestock which would have had difficulty traversing the steep terrain typical of other sections of riverbank would have been able to approach the river at this particular point with far greater ease. Although we must be cautious not to extrapolate broadly from findings from a single core, a borehole drilled near the south-east corner of the Sant'Omobono sanctuary exposed an extremely rare deposit: $40 \mathrm{~cm}$ of animal dung, suggesting that livestock were present in the archaic Forum Boarium. ${ }^{60}$ It is difficult to know the scale of such a 'Cattle Market', but the availability of suitable terrain would certainly have influenced the way livestock in early Rome were maintained and shepherded across the landscape.

\footnotetext{
58 On the 6 masl ground level in these tributary valleys, see Ammerman I998: 217-20; I999; Ammerman et al. 2000: IO-I3; Ammerman and Filippi 2004.

59 Var., Ling. 5.I 46; Festus, Gloss. Lat. 27; also mythical associations with the cattle of Hercules (above, Section I). A bronze statue of an ox later stood in the region (Ov., Fast. 6.477-8; Tac., Ann. I2.24; Plin., HN 34.Io). Dyer I 857: 8I3; Platner and Ashby I929: 224-5; Coarelli I988a: III; Richardson I992: I62-3; Coarelli I995; Cornell I995: 48; Coarelli 2007: 308; Isayev 2017: 82; Cifani 2021: I47-9.

60 The dung was preserved due to anaerobic waterlogged conditions. Radiocarbon analysis on the deposit fell within the Hallstatt plateau, so that its age can only be vaguely placed between the eighth and fifth centuries.
} 
Second, there is new justification for the notion of a ford at this gently sloping shore, which could aid ingress and egress, in the southern part of the Forum Boarium. However, contrary to earlier speculation, a crossing point would not necessarily have relied on slack water created by the Tiber island; it is actually possible that the island did not even exist in this era. ${ }^{6 I}$ Generally speaking, it is safest to ford a river at its widest point, where waters are able to spread and dissipate. Although no sub-surface survey which could help determine the channel width has yet been carried out along the riverbank opposite the Forum Boarium, the location of the east bank indicates a broadening of the river channel (as compared to its modern course). It is therefore likely that waters were slower and shallower here compared to other stretches of the river. People - whether by wading or by riding a cart or animal - and livestock may have found this to be a safe place to cross the Tiber, although possibly only during dry seasons when the river was at its lowest levels (estimated to be less than $2 \mathrm{~m}$ ). Additionally, it is reasonable to hypothesise that another gently sloping shore, comparable to that on the east bank, existed nearby on the west bank. Natural levees or point bar features normally form along the inner banks of river bends; whereas the high-energy outer bend of a meandering river erodes, the lower-energy inner bend deposits sediment. Although it is not yet possible to prove the existence of such a point bar, the laws of river morphology make it likely. The available geoarchaeological evidence, while not definitive, is nonetheless strongly suggestive of the conditions necessary for a ford. Moreover, rivers tend to become deeper as they approach the sea, so is it possible that the first available ford for travellers coming up from the coast was at the site of Rome. ${ }^{62}$ Such a crossing point would have served as a vital nexus for regional transhumance routes and funnelled the movement of people and livestock between Etruria and Latium.

Finally, and perhaps most significantly, the natural topography created conditions suitable for a year-round harbour at the lowest point of the valley. Drawing on ethnographic comparisons in conjunction with archaeological and literary evidence from across the Mediterranean, it is apparent that prehistoric harbours did not require infrastructural investment. Artificial docks or quays would not have been completely necessary, as many seafaring boats were sufficiently lightweight and flat-bottomed to be hauled ashore by a team of men. ${ }^{63}$ Importantly, such flat hulls could navigate the shallower waters of a river and even be propelled upstream by rowing, towing and/or push-pole. Prehistoric sailors who ventured into the mouth of the Tiber and travelled further inland would have eventually arrived at the site of Rome, where they could capitalise on the relatively calm waters and low-lying bank to beach their vessels. Although previous reconstructions of the Forum Boarium valley with a swamp or a high riverbank have led to the conclusion that the site was not suitable as a landing for boats, these notions can now be ruled out. ${ }^{64}$ The low shore where the Velabrum met the Tiber would in fact have been an ideal landing for boats, permitting the loading and unloading of cargo as well as the performance of maintenance. Even during flood events, the gently sloping tributary valleys would have offered continuous access to the shore. As vaguely envisaged by episodes in the ancient literary record (above, Section I),

\footnotetext{
61 The island may have emerged as a result of subsequent changes to the Tiber river, a hypothesis first presented in Marra et al. 2018. Further research on the evolution of the Tiber island will be featured in a future publication from the Forum Boarium Project.

62 Cf. Goiran et al. 2017 , who reconstruct the river as having been up to $6.7 \mathrm{~m}$ in depth in the Tiber channel mouth in the second half of the first millennium B.c.E. Some posit that another crossing existed down-river from Rome at the site of Ficana (e.g. Grandazzi I99I: I I4-I6; Isayev 20I7: 82-4).

63 Blackmann I982: 90-4; Houston I988; Votruba 2017.

64 See Le Gall I953: 93-5, I Io on the swamp. Ammerman and Filippi (2004: I7 n. 37) cite the presence of sixth-century ceramics around 5 masl in order to dismiss the possibility of archaic harbour activity, due to the perceived high elevation of the riverbank.
} 


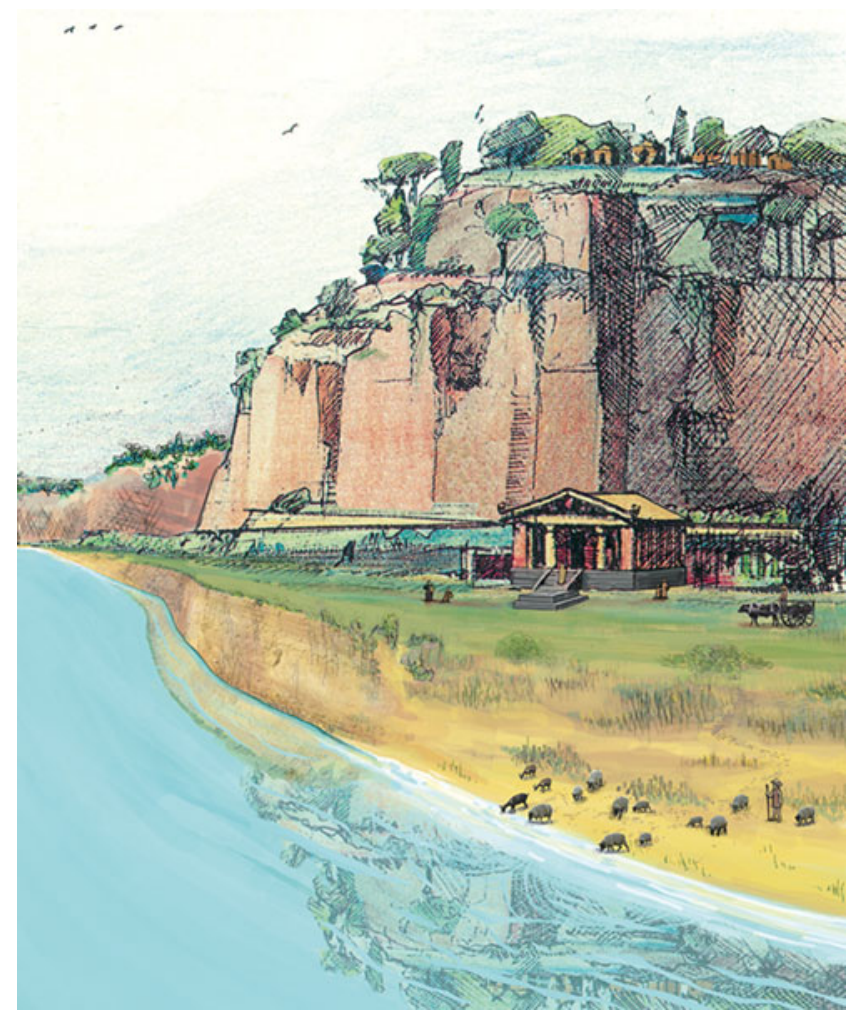

FIG. 5. Visualisation of the early archaic riverbank looking north towards the harbour temple and the Capitoline Hill, depicted with a low river level. (Lorene Sterner, after Ioppolo in Pisani Sartorio I989)

the geoarchaeological evidence suggests that boats could manoeuvre up to and even into the lower Velabrum valley, where they could be safely beached in the shadow of the Palatine Hill regardless of the season or river level.

\section{Archaic River Harbour Temple}

Beside this (presumably bustling) low-lying shore, the northern section of riverbank in the Forum Boarium stands out as a particularly strategic location, at an elevation around 6.5 masl. Situated some $6 \mathrm{~m}$ above the river below, this part of the landscape would have offered good visibility of river traffic, as well as considerable protection from floodwaters. The prominence of this spot is arguably confirmed by one of the earliest constructions of the nascent city: the archaic temple building of the Sant'Omobono sanctuary, built atop the high riverbank in the early sixth century. This is Rome's first archaeologically known temple (and one of the earliest in central Italy), erected three generations before Rome's supreme god, Jupiter Optimus Maximus, had a finished house on the hilltop above. ${ }^{65}$ The smaller and older temple in the shadow of the Capitoline provided an impressive, multicultural backdrop for the myriad of happenings along the river (Fig. 5). ${ }^{66}$ This temple, variously attributed to the goddesses Fortuna or

65 Diffendale et al. 2016; Brocato and Terrenato 2017.

66 On the Latin, Greek and Etruscan elements of the temple's design and iconography, see Hopkins 2016: 53-65; Diffendale et al. 2016: I3-I4. 
Mater Matuta (above, n. 28), oversaw a critically important liminal zone in Rome, where locals could interact with foreigners and neighbours. Although excavations at Sant'Omobono have afforded only a few narrow windows into the archaic levels of the site, it is likely that any space on the riverbank not actively being used for cult matters would have hosted a wide variety of river-related activities, such as market pursuits or the temporary storage of goods. ${ }^{67}$

When building in the river valley, the archaic inhabitants of Rome surely acted with intimate familiarity with the Tiber's seasonal behaviour and made informed decisions about necessary flood-mitigation measures. Exposure to flood waters would have catastrophically eroded the temple's mudbrick superstructure, undermining its elaborate terracotta décor and ruining the wooden cult statue housed within. We can be confident that inhabitants would not have invested such economic and cultural resources in a position that was perceived to be susceptible to inundation. Positioned atop this natural ledge at 6.5 masl, a I.7 m high podium - made from an unusually dense variety of tufo lionato imported from the Anio region that would have been more resistant to water damage than local stone ${ }^{68}$ - further lifted the temple's vulnerable superstructure to an elevation of 8.2 masl. For comparison, it is important to note the first gravel surface of the nearby Forum Romanum, where an archaic land-reclamation project filled the valley and raised the ground level to 8.6 masl. ${ }^{69}$ These two elevations provide a strong indication of the height perceived to be 'safe' in the early sixth century. It is also worth reiterating that our investigations have documented pre-republican flood deposits only as high as 7.4 masl, this being the upper limit of the land surface beneath the Sant'Omobono sanctuary. While determining the magnitude of ancient flood events is difficult for reasons acknowledged above, this combination of topographical and archaeological evidence offers compelling proxies. We suggest that at the time the harbour temple was built, a flood reaching more than 8 masl would have been an exceedingly rare event. ${ }^{70}$ It seems that Rome's first monumental temple, unsurprisingly, was erected in a position that was highly visible as well as offering relative safety from inundations (Fig. 6).

\section{TRANSFORMATION OF THE RIVER VALLEY}

\section{The Shifting Tiber and the Formation of a New Riverbank}

Over the course of the sixth century, Rome's fluvial system became unstable, and the river valley began a significant transformation. While the plain along Via Petroselli and the Lungotevere had previously been subjected to intense erosive forces that had kept the surface in or near the active river channel very low (c. I mbsl), the area now began to fill with sediments deposited by water. This accumulation was clearly not the result of anthropic dumps or building projects, which would have served to indicate that the modification of Rome's riverbank was the result of reclamation projects or general urban encroachment. ${ }^{7 \mathrm{I}}$ Instead, the stratigraphy consists of layers of silts, like those found in seasonally dry floodplain environments, and is observable in cores across the

67 Another reason for the temple's diminutive size (cf. Brocato et al. 2019).

68 Brocato et al. 20I9; revising Diffendale et al. 20I6: I I-I2.

69 Ammerman I990; Hopkins 2016: 30.

70 Earlier estimates put flood levels at Rome in the regal period at higher elevations, between 9 and I I masl (Ammerman I990: 637-8; Ammerman and Filippi 2004: 16, 24; Ammerman 2018: 399-400; Bellotti and Bianchi 2019).

71 As vaguely envisioned by Ammerman (2006: 307; 201 8: 407-8). 


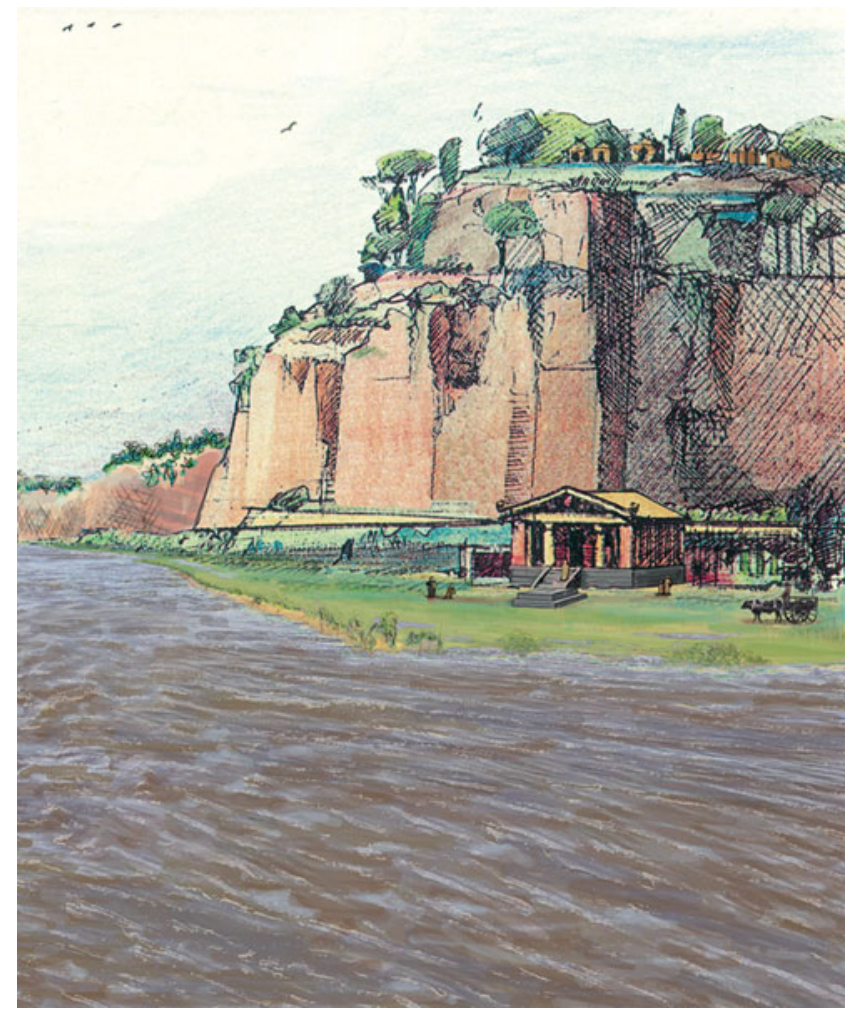

FIG. 6. Visualisation of the early archaic riverbank looking north towards the harbour temple and the Capitoline Hill, depicted with a high river level. (Lorene Sterner, after Ioppolo in Pisani Sartorio 1989)

Forum Boarium. ${ }^{72}$ Simultaneously, and perhaps in response to this sediment newly accumulating along its east bank, the Tiber river began shifting westward towards its modern course. It is difficult to determine whether the sedimentation along the east bank prompted the shift in the river's course or was a consequence of it, as the two processes are inextricably linked. Regardless of the precise reasons for the river's movement, the hydrological and topographic changes in the Forum Boarium valley are apparent. ${ }^{73}$ The erosive power of the river and its two tributary streams was no longer counteracting the depositional forces as it once had. As the area filled with fluvial sediments, the ground level was raised and extended westward over time: a high, wide riverbank emerged in the valley between the Capitoline and Aventine Hills.

The chronology of this sediment accumulation along the Tiber's east bank is secure. Although there are infrequent anthropic inclusions within this thick horizon of silt deposits, abundant ceramic evidence from the abandoned river channel found at

\footnotetext{
72 Granulometric analyses show these deposits to be predominantly silt, although fine sands are more prevalent in the lower part of the sequence (which is consistent with the initial formation of levee features in the marginal zones along river channels). Sampling produced only rare macrobotanical remains. The full spatial scale of the sedimentation is unclear, but a wider coring survey would allow us to test whether the sedimentation was isolated to the Forum Boarium region.

${ }^{73}$ This shift in the Tiber's position could have also been the result of the natural vicissitudes of a meandering river, or may have been prompted by tectonic displacement along fault lines in the area. The latter hypothesis is presented in Marra et al. 2018 and is the subject of ongoing study.
} 
elevations around I mbsl (above, Section III) provides a clear terminus post quem: the westward shift of the Tiber's course and the intensive sedimentation commenced after the beginning of the sixth century. Furthermore, a massive renovation at the site of Sant'Omobono in the early fifth century B.C.E. confirms that the sedimentation occurred rapidly and had immediate implications for operations in the river valley. Excavations have demonstrated that the temple, built atop the high section of riverbank in the early sixth century, was abandoned by the end of the century. In the decades that followed, a monumental platform, measuring $c .47 \mathrm{~m}$ per side and standing roughly $5 \mathrm{~m}$ in height, buried and supplanted the archaic cult site with a new sanctuary complex that included twin temples of Fortuna and Mater Matuta. ${ }^{74}$ Core 47 exposed tuff blocks from a low western shoulder or terracing wall associated with this early fifth-century platform, covering a thick pack of fluvial sediments (Fig. 7). ${ }^{75}$ As well as revealing a previously unknown architectural feature, this discovery provides an important terminus ante quem for the accumulation from I mbsl up to 5 masl. ${ }^{76}$ Taken together, even the longest and most conservative timeline is staggering: nearly $6 \mathrm{~m}$ of sediment was deposited beside the older riverbank over the course of the sixth century. ${ }^{77}$ In addition to core 47 , boreholes from the central and eastern Forum Boarium (43, 50, 5I, 52 and 54) all exposed comparable sedimentation up to and beyond 5 masl. The evidence, therefore, indicates that a high riverbank gradually subsumed the pre-existing low-lying shore in the southern part of the Forum Boarium after the beginning of the sixth century.

While it is clear that this process of fluvial transformation began sometime in the sixth century, it continued well into the republican period. Cores further west $(39,44,45,46$, $48,55,57$ and 58) exposed a similar sequence of silts, but with more prolific inclusions of ceramic sherds, several of which are mid-republican. ${ }^{78}$ In other words, the Tiber seems to have moved westward gradually, while overbank flooding and sedimentation progressively widened and elevated the floodplain through the early and mid-Republic. Fluvial sediments accumulated in the area of the Forum Boarium at least until the third century B.C.E.; floodplain silts, which are physically beneath and chronologically before anthropogenic deposits with inclusions of mortar fragments, are found up to 7 masl in cores in the southern Forum Boarium and up to 9 masl further north. ${ }^{79}$ In some areas, the ground level had risen by more than Io $\mathrm{m}$ as a result of siltation since the beginning of the sixth century. Even as the valley filled, the southern part of the Forum Boarium continued to be one of the lowest points in the city, leaving a visible imprint of the original harbour.

The progressive river movement and formation of the new riverbank from the sixth century onwards would have been acutely perceptible to local inhabitants: the

74 Diffendale et al. 2016: 20-8.

75 A $2 \mathrm{~m}$ deposit of tufo del Palatino (cappellaccio) covered by $0.5 \mathrm{~m}$ of lapis Albanus, matching the material for the core and sheath, respectively, of the first phase of the republican platform at Sant'Omobono (Diffendale et al. 2016: 22-3). Although we cannot yet prove that this architectural feature extended along the length of the platform, we hypothesise that it served as a terrace by encasing the upper ledge of the pre-existing riverbank, thereby creating a paved surface (of indeterminate size) at the base of the platform at 7.5 masl.

76 Although Ammerman and Filippi (2004: I6-I7 n. 37) similarly documented a late sixth-century stratigraphic horizon around 5 masl along the riverbank, they mistakenly assumed that this marked the natural land surface at the base of the archaeological sequence, and that the deeper alluvial sequence had naturally and slowly accumulated since the fourth millennium, an inference seemingly based on a single problematic radiocarbon date. 77 Further (negative) evidence for the pace of the sedimentation is the absence of apparent soil formation processes, which might otherwise occur if a surface was left exposed and stable for an extended period of time.

78 This collection includes post-sixth-century sherds identified as Italian black gloss, creamware and opaque red ware, in addition to commonware and internal slip ware, both of which are attested in the Archaic Period and the mid-Republic.

79 Mortar is associated with the technological innovation of concrete in the mid-second century B.C.E. (Mogetta $2015)$. 


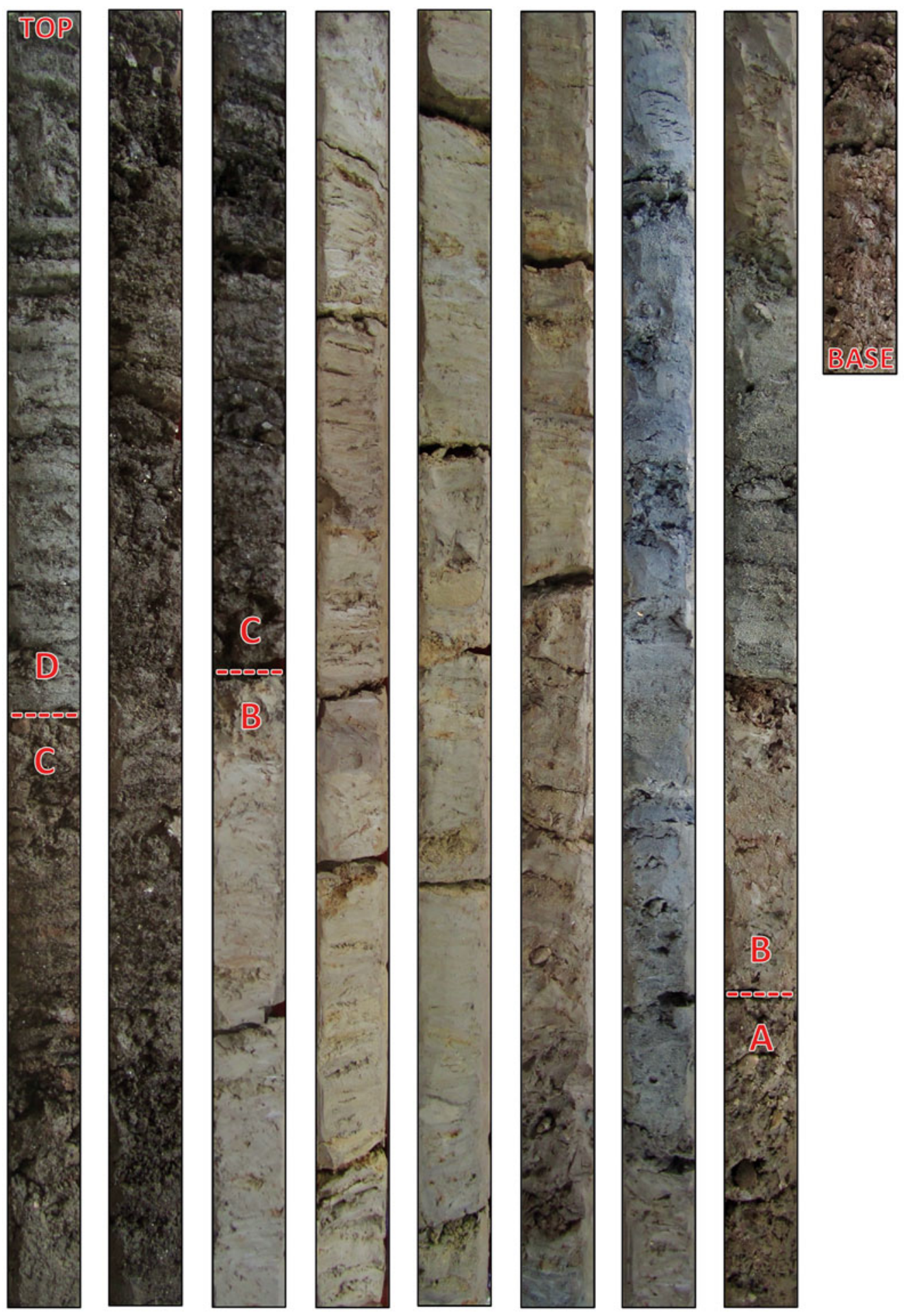




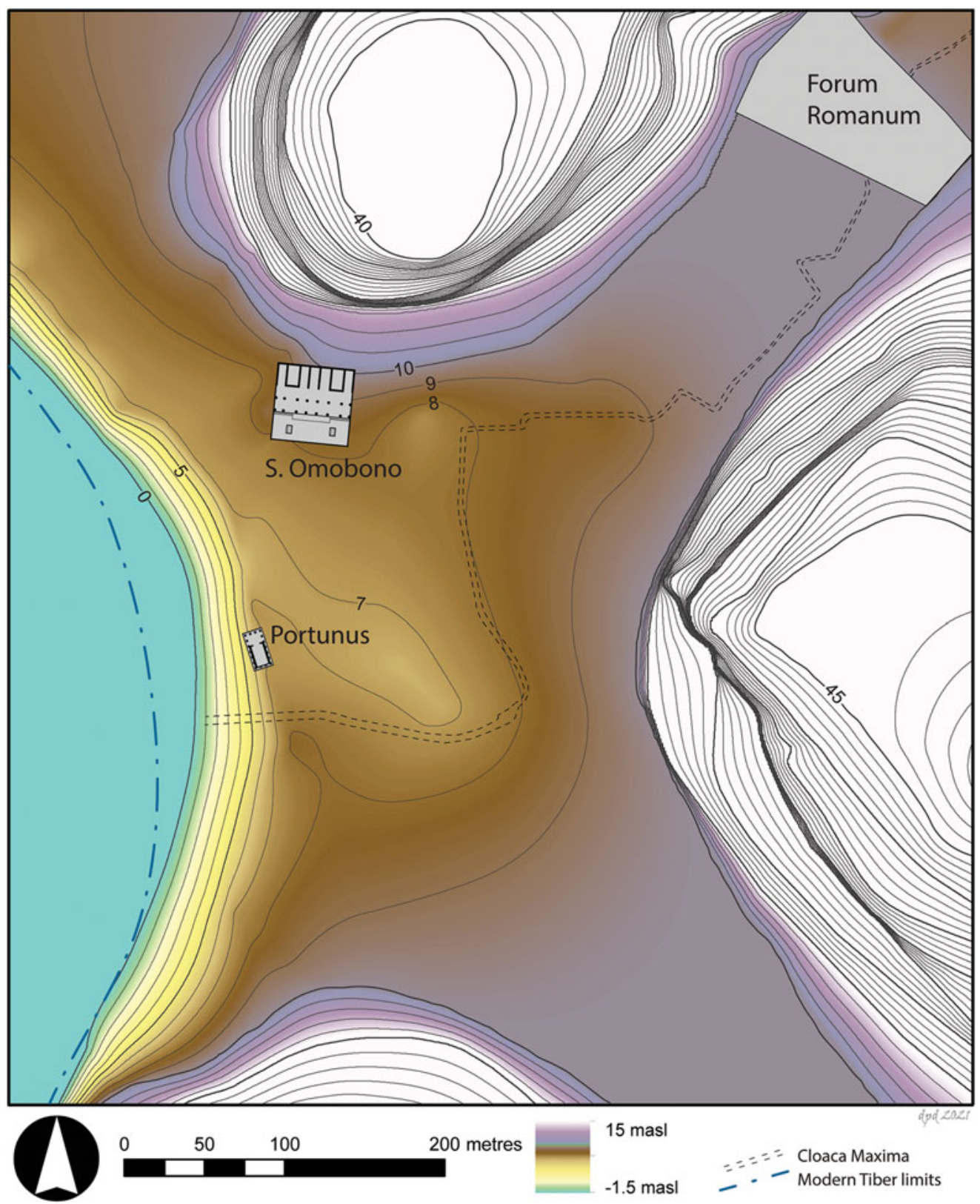

FIG. 8. Topographic reconstruction of the mid-republican riverbank in the Forum Boarium, noting the position of key structures or features mentioned in the text. (Daniel P. Diffendale)

FIG. 7. (opposite). Photographs of core 47 from $0.8 \mathrm{mbsl}$ at the base to 7.5 masl at the top, showing key stratigraphy including: (A) deposits associated with the early archaic river channel; (B) floodplain deposits associated with the sixth-century sedimentation; as well as (C) cappellaccio and (D) lapis Albanus tuff blocks associated with the early fifth-century platform at the Sant'Omobono sanctuary. (Andrea L. Brock) 
conditions that had once facilitated a natural harbour and ford at Rome's shore would have disappeared by the beginning of the republican period. By the third century B.C.E., the Tiber flowed further from the city, and a new riverbank stretched between the Capitoline and Aventine Hills (Fig. 8). In order to comprehend and appreciate the Romans' responses to these substantial changes, it is necessary to consider first the causes and effects of this transformation.

\section{Inferring Causes: Urbanisation}

One of the most dynamic natural forces on the planet, rivers are complex systems that are highly susceptible to changes within their broader environment. Even subtle adjustments to water or sediment inputs or outputs across the regional watershed can impact a river's depositional and erosional behaviour. For these reasons, it is difficult to identify with certainty the causes of this transformation of Rome's river valley, but we can offer reasonable inferences.

At least two natural factors might have contributed to the newly documented sedimentation process. First, as the Tiber shifted westward, the older sections of river channel along Via Petroselli were especially prone to siltation. With the river's course moving further away, this newly established, marginal zone would have been subjected to overbank flooding, but shielded from the river's strongest erosive force. Second, a wetter regional climate could have caused increased erosion, correlating to more water and sediment being washed into the river. Although there is some evidence for higher levels of precipitation in the mid- to late Holocene, there is insufficient data to demonstrate the spike in rainfall in this particular period which would be necessary to account for the siltation documented in the Forum Boarium. Such climatic variability ought to be identifiable in the sedimentary records from other lakes and rivers in the area, but clear parallels for the phenomenon observed at Rome are currently lacking. ${ }^{80}$

In addition to these natural factors, human impact is a significant potential cause of the sedimentation. More than a dozen major building projects at Rome are dated archaeologically between the late seventh and the early fifth century B.C.E. ${ }^{8 \text { I }}$ This urban growth would have necessitated extractive ventures on the landscape in and around Rome: quarrying for stone, as well as deforestation for construction material and fuel..$^{82}$ These activities, especially when operating at scale, would result in increased surface runoff and sediment influx in the river valley. Additionally, we can assume that the installation of drainage channels would have seriously exacerbated the situation. Whereas two tributaries once met the Tiber somewhere in the area north of the Aventine Hill, these streams were eventually canalised. ${ }^{83}$ While this infrastructural investment would have aided drainage and drying further up the valley (as in the area of

\footnotetext{
80 Future climatic and geological research could certainly revise the current picture. On the evidence for climate variability and comparisons between the sedimentary record in the Forum Boarium and elsewhere in the region, see Marra et al. 20I8: I3-I4.

81 I) landfill and paving to create the Forum Romanum; 2) drainage channels including the Cloaca Maxima; 3 ) archaic harbour temple at Sant'Omobono; 4) Regia; 5) Temple of Castor; 6) Temple of Saturn; 7) Atrium Vestae; 8) monumental platform at the site of the Comitium; 9) Capitoline Temple and associated terracing structures; Io) early republican platform and twin temples at Sant'Omobono; I I) elite domestic structures on the north slope of the Palatine; I2) first phase of the villa at the Auditorium site; I3) sections of the so-called Servian fortification wall (debated). See above, n. 47.

82 Substantial quantities of fuel would also have been necessary to support terracotta production (cf. Ammerman et al. 2008). Although there are unfortunately no contemporary pollen data from Rome to test such a deforestation hypothesis, palynological studies in central Italy do generally indicate a decrease of deciduous forest and increase in cultivated plants in this period (Mercuri and Sadori 20I2; Stoddart et al. 20I9).

83 The precise path and chronology of Rome's archaic drainage system remains somewhat unclear, in part because it was reconstructed repeatedly over time. For the available evidence, see Hopkins 2007; Bianchi $2018 ; 2020$.
} 
the Forum Romanum), the streams' seasonal movement and naturally erosive behaviour would have been restricted wherever they were encased in their channels. Once these streams were no longer free to erode laterally across their respective valleys, sediment deposited during overbank flood events would continuously accumulate and (in the areas outside of the Tiber's active channel) remain uneroded. This (probably unforeseen) repercussion of Rome's drainage infrastructure would have the largest implications for the lowest part of the valley, precisely the area most prone to flooding. For centuries and millennia, a section of the east bank of the Tiber had been kept low by the erosive force of the tributary streams; the conversion of this confluence into the mouth of the Cloaca Maxima would have had a dramatic impact. ${ }^{84}$

It is not yet possible to distinguish and quantify with certainty the degree to which natural and anthropic forces contributed to the transformation of Rome's river valley. The correlation between the chronology and scale of urbanisation at Rome and the siltation in the Forum Boarium valley is, however, quite striking. We suggest that the two phenomena are logically related. Rivers are extremely prone to anthropically driven change. As urbanisation processes at Rome reshaped the natural topography of the site from the sixth century onwards, it would necessarily have had repercussions for the Tiber river - and especially the region around the original river harbour. Whether the early inhabitants of Rome understood the connection between their urban endeavours and the changing topography of their river valley is unfortunately obscured by the lack of a contemporary literary record. However, inhabitants were undoubtedly keenly aware of the intensifying threat of floods that tracked their urban growth.

\section{Inferring Effects: Escalating Floods}

While Rome's valleys indisputably flooded in the prehistoric era, this probably did not create tremendous problems. On the one hand, there was simply less infrastructure in the valleys at risk of inundation: early urban investments seem to have been clustered on elevated sections of the landscape, including the high ledge at the base of the Capitoline Hill and the reclaimed land in the Forum Romanum. On the other, the available evidence suggests that floods in the early Archaic Period rarely, if ever, exceeded 8 masl. Furthermore, we should envision floods at Rome as seasonal and somewhat predictable, so that activity in parts of the valley susceptible to inundation could be readily relocated or temporarily disbanded. However, this hydrological reconstruction is only applicable to the relatively unmodified landscape and stable fluvial system that existed until the sixth century.

Coring evidence indicates that flood levels at Rome increased markedly from the sixth century onwards. As the lowland filled with sediment and the ground level of the riverbank district rose and pushed westward, floodwaters had ever less room to spread and would have climbed to progressively higher elevations. This reconstruction, therefore, provides a compelling reason for the radical overhaul of the Sant'Omobono sanctuary at the turn of the sixth-fifth centuries B.C.E.: whereas the archaic harbour temple was once situated in a safe position several metres above the river, in the two or three generations that followed, the area became subjected to novel sedimentation and hydrological forces. The 2013 deep trench excavation at Sant'Omobono revealed a layer of fluvial sediments covering archaic levels and deposited near the temple podium; this may be the remnants of a flood capable of affecting the mudbrick temple. After the abandonment of the archaic temple, the early republican construction effectively re-established the topography as it once was: a (now artificial) terrace projecting from

84 In response to the shifting river and inflation of the riverbank from the sixth century onwards, westward extensions may have been made to the Cloaca Maxima over time. 
the side of the Capitoline Hill, standing several metres above the river below. Seated atop this platform at an elevation of I 3 masl, the twin temples of Fortuna and Mater Matuta were presumably in a position that afforded relative safety from most contemporary floods.

Over the centuries, valley reclamation projects and general urban encroachment would have further constrained floodwaters and amplified their height. ${ }^{85}$ Whereas floods had deposited sufficient sediment to raise the ground level in the Forum Boarium to 9 masl by the mid-Republic, flood sediments are found as high as II masl. The historical record, furthermore, documents the recurrent challenge of Tiber floods, which exceeded I 5 masl by the first centuries B.C.E./C.E.. ${ }^{86}$ Floods on this scale may have been comparatively rare events, but the general trend is nonetheless apparent from the geoarchaeological and literary evidence: even as the ground level rose substantially, Rome's lowlands became ever more susceptible to inundation. As the river valley and the city itself rose, the Tiber responded in kind with floods reaching increasingly higher levels.

The dire situation is evocatively illustrated by voices from the ancient literary record. For example, an exceptional flood that struck Rome in early March of 69 C.E. was remembered as an alarming prodigy of the tumultuous events of that year. A young man of thirteen at the time, Tacitus may personally have witnessed the episode, which he notes 'flooded not only the low-lying and level areas, but also those usually safe from this sort of catastrophe'. He goes on to recount the consequences for the city's lowlands: 'Many were swept away from the public squares and many more were cut off in their shops or beds. The foundations of apartment buildings were degraded by the stagnant waters, only to collapse when the river receded'. ${ }^{87}$ The Romans needed either to adapt their lowland activities progressively over the centuries, or to accept the periodic destruction and devastation wrought by the Tiber. Few, if any, other urban communities in central Italy faced environmental challenges of such existential import.

\section{THE EMERGENCE OF ROME'S HISTORICAL RIVERBANK}

Romans of the mid-Republic had a very different riverbank district than their archaic predecessors. It became, for one thing, a much larger region. Instead of being restricted to the high ledge beneath Sant'Omobono and the low shore at the termination of the Velabrum valley, a long and wide swath of new riverbank evolved between the Capitoline and Aventine Hills. Although the recently formed real estate in Rome's river valley would offer new opportunities, the implications for Rome's original harbour are profound. As the valley filled and the ground level rose, the river hydrology would have also changed. This area, formerly characterised by a wider channel and dissipated waters, would have been constricted, so that the water may have begun to flow deeper and faster. Moreover, the formation of a high riverbank would have been far less accommodating for harbour and fording activities, at least as they had conceivably once operated.

This story of Rome's original river harbour should, therefore, be understood as a prologue to the well-known challenge later faced by Rome of maintaining port operations in the face of silting at Ostia and Portus. The dynamism of the riparian

\footnotetext{
85 A phenomenon previously inferred to justify, for example, the need to progressively raise the floor of the Forum Romanum (Hopkins 2016: 28-30; Bellotti and Bianchi 2019).

86 Aldrete 2007: I3-33, 8I-9.

87 Tac., Hist. I.86: 'non modo iacentia et plana urbis loca, sed secura eius modi casuum implevit: rapti e publico plerique, plures in tabernis et cubilibus intercepti ... corrupta stagnantibus aquis insularum fundamenta, dein remeante flumine dilapsa'.
} 
landscape would have serious ramifications for the nascent city and its ability to continue capitalising on the flow of people and goods between Etruria, Latium, Campania and the wider Mediterranean after the sixth century. The natural advantages offered by the site faded as the city grew, leading to new and unforeseen challenges. At a time when Rome was a regional leader, but still centuries away from establishing an imperial road network, the maintenance of transit lines and river operations would have been vital for the city's continued prosperity. This was a challenge that demanded an adaptable community.

Rather than being pulled up onto a low shore, boats arriving at Rome in the republican period would have required mooring structures along the riverbank: a proper port, not just a natural harbour. Although we lack clear-cut evidence for the earliest port infrastructure in the Forum Boarium, the cores do show sporadic indications of anthropic fill deposits and stone constructions that could be associated with embankment walls or other port works. Unlike the high walls that separate the Tiber river from the modern city, embankments at Rome in the ancient period were disjointed and low at points; flood containment, therefore, was likely not the intended objective. Instead, these embankment walls served other important purposes: shielding the riverbank from erosion and serving as quays at which boats could be tied and stabilised broadside to the bank for the purposes of unloading goods. ${ }^{88}$ The low terracing wall arguably associated with the early fifth-century renovation of the Sant'Omobono sanctuary (above, Section V) could, in theory, have facilitated port activity alongside the high riverbank in the northern part of the Forum Boarium. Although difficult to prove from the extant evidence, such a hypothetical reconstruction of early port infrastructure adjacent to the Sant'Omobono sanctuary would account for the placement and orientation of the Temple of Portunus, with its back to the archaic harbour due south, facing north towards what may have been the early republican port. In any case, the position of early embankment walls and quays would probably have required periodic adjustment, as the borehole record makes it clear that overbank flood sediments continued to accumulate in the area of the Forum Boarium into the mid-Republic.

The process of urbanising a river valley changes the ecology: once an area is paved, it is logical to expect that any silts deposited during a flood event would be cleaned up, rather than being left in situ and allowing the surface to aggrade gradually. In other words, once a floodplain is urbanised, land inflation as a result of sediment accumulation is halted, while urban infrastructure in the area remains extremely vulnerable to flood waters. In the case of the stretch of land between the Capitoline and Aventine Hills, fluvial sediment was deposited at least into the third century; only then, it seems, was the area extensively paved or built up. Although this area along the river had certainly been a major hub of activity since the beginning of sedentary habitation at the site, the significant degree of landscape change and land inflation in the river valley suggests that human activities must have been ephemeral or supported with limited built infrastructure (with the exception of the Sant'Omobono sanctuary) until the third century B.C.E.

Both the archaeological and literary records confirm that the Romans made major investments in the Forum Boarium in the mid-Republic, reinforcing the riverbank and limiting further changes to the fluvial topography. ${ }^{89}$ Excavations at the Temple of Portunus and the Round Temple have revealed that both structures rest atop embankment walls, which were constructed sometime between the late fourth and early

88 Aldrete 2007: 192-8; Muzzioli 2009.

89 In addition to the projects discussed here, Livy mentions a variety of new or pre-existing structures in the Forum Boarium specifically: a three-story building which existed in 2 I 8 (21.62.2-4); the construction of a road to the Circus Maximus in 204 (29.37.2); the installation of two arches with golden decorations in 196 (33.27.4); numerous buildings and shops along the Tiber that were destroyed by a fire in I92 (35.40.8). See Coarelli I988a: 60-204; Ziółkowski I992; Davies 2017 for the mid-republican investments in the region. 
second centuries B.C.E. ${ }^{90}$ This broadly reflects the western edge of the siltation and the newly established position of the riverbank. The course of the Tiber river as it flowed through Rome became relatively static thereafter. Livy mentions the installation of extensive port infrastructure along the Tiber bank in the first half of the second century B.C.E.: his account is vague, but generally indicative of efforts to build or refurbish pre-existing riverside walls, quays and porticos. ${ }^{9 \mathrm{I}}$ Even after the position of the riverbank and river channel stabilised, Rome's riverside infrastructure would have required regular maintenance over time: at a minimum, reinforcement of the Tiber bank and dredging to clear a path for boats to manoeuvre. ${ }^{92}$ It is perhaps not surprising, therefore, that from at least the Late Republic a series of bureaucratic offices (curatores riparum and the like) were established to handle issues of river management. ${ }^{93}$

The river's movement and sedimentation from the sixth through the third centuries created the land that would be known as the Forum Boarium: a high riverbank monumentalised with temples and crowded with port infrastructure and market activities. The developed riverbank familiar to ancient and modern authors shared little resemblance with the unencumbered shore that existed before the growth of the city. Although this process of urbanising the riverbank helped to stabilise the landscape in the Forum Boarium, it also meant that structures were built in areas at risk of flooding on an annual basis, creating new and enduring challenges for the inhabitants of the Eternal City. ${ }^{94}$

\section{CONCLUSION}

Rome's disjointed hills and flood-prone valleys were not perfectly conducive for the growth of a city, but the site was nonetheless strategic. Our geoarchaeological research provides the first empirical evidence not only for a natural river-crossing and landing for boats, but also for an elevated section of riverbank that provided a safe place for the growth of river-related infrastructure. These unique conditions both incentivised and facilitated urbanisation. As the settlement took an increasingly urban form in the sixth century, this opportune river valley - which had arguably helped the Romans become players on the Italian and Mediterranean stage - was radically transformed. Sometime around the beginning of the Republic, Rome's original river harbour ceased to exist as the area silted up. In the face of dynamic ecological conditions and escalating floods, the maintenance of commercial enterprises would have required a sophisticated socio-political system: a centralised authority, organised and communal effort, surplus resources and labour and strategic urban planning. Generations of Romans responded proactively by adjusting their riverbank activities and harbour infrastructure. The inhabitants' adaptive measures, which occurred promptly in response to the instability of the Tiber in the sixth century and continued for centuries thereafter, serve as a testament to the ingenuity and resilience of the community. While the Romans are renowned for their ability to exploit, modify and overcome challenging landscapes across their Empire, the reality is that they had been doing so 'at home' from the very origins of their city.

Ultimately, it is becoming clear that building the Eternal City was not a linear, predetermined, or easy process. The form and trajectory of Rome's prehistory was

90 Rakob and Heilmeyer I973; Cressedi I984; Colini et al. I986; Ruggiero I991-92; Adam I994.

91 Livy 35.IO.I 2, 40.5 I.4-6, 4I.27.8. Aldrete 2007: I94; Tuck 20I3: 329.

92 E.g. Suet., Div. Aug. 30; Tac., Ann. г.76.

93 Aldrete 2007: 198-203.

94 See Aldrete 2007 for a comprehensive survey of flooding at Rome in the historical period. 
shaped (not exclusively, but to a meaningful degree) by the opportunities and challenges offered by the natural landscape - and the contours of the ecological situation changed profoundly alongside societal growth at the site. By elucidating these complex humanenvironment negotiations, we stand to gain new perspectives on the social and political developments in early Rome, the very processes that created the vibrant republican society that eventually emerged from the murky waters of prehistory. By illuminating the stage that was the landscape of early Rome, it becomes possible to see the actors more clearly, and to understand how the drama changed with each act.

University of St Andrews

andrea.brock@st-andrews.ac.uk

University of Michigan

lmotta@umich.edu

University of Michigan

terrenat@umich.edu

\section{BIBLIOGRAPHY}

Adam, J.-P. I994: Le temple de Portunus au Forum Boarium, Rome.

Aldrete, G. S. 2007: Floods of the Tiber in Ancient Rome, Baltimore, MD.

Alföldi, A. 1965: Early Rome and the Latins, Ann Arbor, MI.

Ammerman, A. J. I990: 'On the origins of the Forum Romanum', American Journal of Archaeology I04, 627-45.

Ammerman, A. J. I998: 'Environmental archaeology in the Velabrum, Rome: interim report', Journal of Roman Archaeology II, 213-23.

Ammerman, A. J. I999: 'Velabrum (Environmental Setting)', in E. M. Steinby (ed.), Lexicon Topographicum Urbis Romae, Vol. V, Rome, IоI-2.

Ammerman, A. J. 2006: 'Adding time to Rome's imago', in L. Haselberger and J. Humphrey (eds), Imaging Ancient Rome, Portsmouth, RI, 297-308.

Ammerman, A. J. 20I8: 'The east bank of the Tiber below the Island: two recent advances in the study of early Rome', Antiquity 92, 398-409.

Ammerman, A. J. and Filippi, D. 2004: 'Dal Tevere all'Argileto: nuove osservazioni', Bullettino della Commissione Archeologica Comunale di Roma I05, 7-28.

Ammerman, A. J., Iliopoulos, I., Bondioli, F., Filippi, D., Hilditch, J., Manfredini, A., Pennisi, L. and Winter, N. A. 2008: 'The clay beds in the Velabrum and the earliest tiles in Rome', Journal of Roman Archaeology 21, 7-30.

Ammerman, A. J., Miller, J. and Ramsay, S. 2000: 'The mid-Holocene environment of the Velabrum in Rome', Società per la Preistoria e Protostoria della Regione Friuli-Venezia Giulia 8, 9-19.

Baroni, I. 2003: 'Livelli di occupazione dell'età del Bronzo nel Giardino Romano: il Bronzo recente', Bullettino della Commissione Archeologica Comunale di Roma IO2, $29 \mathrm{I}-8$.

Bellotti, P. 2020: 'La valle dello Spinon nel quadro evolutivo olocenico del basso corso del Tevere', in E. Bianchi and M. D'Acunto (eds), Opere di regimentazione delle acque in età arcaica, Rome, $39 I-402$.

Bellotti, P. and Bianchi, E. 20I9: 'Velabrum minus: variazioni topografiche dalle origini di Roma alla prima età imperiale. Tra morfologia e sviluppo urbano', Agri Centuriati I6, 33-46.

Beloch, K. J. I926: Römische Geschichte bis zum Beginn der punischen Kriege, Berlin.

Benedetti, F., Bussaglia, R., Fulminante, F., Guidi, A. and Stamerra, L. 2020: 'Rome: old and new data on the birth and development of the protourban centre', Origini 43, I7I-208.

Bianchi, E. 20г 8: 'Projecting and building the Cloaca Maxima', in E. Tamburrino (ed.), Aquam ducere, Seren del Grappa, I77-204.

Bianchi, E. 2020: 'L'opera idraulica dei Tarquini. Nuove indagini sui resti del condotto nel Foro Romano e ipotesi sul percorso fino al Tevere', in E. Bianchi and M. D’Acunto (eds), Opere di regimentazione delle acque in età arcaica, Rome, 46I-546. 
Blackmann, D. J. I982: 'Ancient harbours in the Mediterranean. Part I', International Journal of Nautical Archaeology II (2), 79-IO4.

Bradley, G. 2020: Early Rome to 290 BC: The Beginnings of the City and the Rise of the Republic, Edinburgh.

Brocato, P., Diffendale, D. P., Di Giuliomaria, D., Gaeta, M., Marra, F. and Terrenato, N. 20I9: 'A previously unidentified tuff in the archaic temple podium at Sant'Omobono, Rome and its broader implications', Journal of Mediterranean Archaeology 32, I I4-36.

Brocato, P. and Terrenato, N. (eds) 20I3: Nuove ricerche nell'area archeologica di S. Omobono Roma, Arcavacata di Rende.

Brocato, P. and Terrenato, N. 2017: 'The archaic temple of S. Omobono: new discoveries and old problems', in Lulof and Smith 2017, 97-106.

Brock, A. L. 20I6: 'Envisioning Rome's prehistoric river harbor: an interim report from the Forum Boarium', Etruscan Studies I9, I-22.

Brock, A. L. 20I7: Rome at Its Core: Reconstructing the Environment and Topography of the Forum Boarium, PhD Diss., University of Michigan.

Brock, A. L. 2018: 'Exposing Rome's archaic landscape: recent geoarchaeological investigations at and around S. Omobono', in P. Brocato, M. Ceci and N. Terrenato (eds), Ricerche nell'area dei templi di Fortuna e Mater Matuta (Roma), Vol. II, Arcavacata di Rende, 9-24.

Brock, A. L. and Terrenato, N. 2016: 'Rome in the Bronze Age: late second-millennium BC radiocarbon dates from the Forum Boarium', Antiquity 90, 654-64.

Buzzetti, C. I999: 'Portus Tiberinus', in E. M. Steinby (ed.) Lexicon Topographicum Urbis Romae, Vol. IV, Rome, I 5 5-6.

Campbell, J. B. 201 2: Rivers and the Power of Ancient Rome, Chapel Hill, NC.

Carandini, A. I997: La Nascita di Roma, Turin.

Carandini, A. 2007: Roma: il primo giorno, Rome.

Carpentieri, E., de Rita, D. and Monica, G. D. 2015: 'Geology of the Murcia valley and flood plain modifications in the construction of the Circus Maximus, Rome, Italy', Geoarchaeology 30 , $483-94$.

Cazzella, A. 200I: 'Sviluppi verso l'urbanizzazione a Roma alla luce dei recenti scavi nel Giardino Romano', Bullettino della Commissione Archeologica Comunale di Roma 102, 265-8.

Cifani, G. 202I: The Origins of the Roman Economy, Cambridge.

Coarelli, F. I968: 'Navalia, Tarentum e la topografia del Campo Marzio meridionale', Quaderni dell'Istituto di Topografia Antica 5, 27-38.

Coarelli, F. I977: 'Il Campo Marzio occidentale. Storia e topografia', Mélanges de l'École française de Rome. Antiquité 89, 807-46.

Coarelli, F. I988a: Il Foro Boario: dalle origini alla fine della repubblica, Rome.

Coarelli, F. I988b: 'I santuari, il fiume, gli empori', in A. Momigliano and A. Schiavone (eds), Storia di Roma, Vol. I, Turin, I27-5I.

Coarelli, F. I995: 'Forum Boarium', in E. M. Steinby (ed.), Lexicon Topographicum Urbis Romae, Vol. II, Rome, $295-7$.

Coarelli, F. 2007: Rome and Environs: An Archaeological Guide, Berkeley, CA.

Colini, A. M. I980: 'Il porto fluviale del Foro Boario a Roma', in J. H. D’Arms and E. C. Kopff (eds), The Seaborne Commerce of Ancient Rome, Rome, 43-53.

Colini, A. M., Pisani Sartorio, G. and Buzzetti, C. I986: 'Portus Tiberinus', in S. Quilici Gigli (ed.), Il Tevere e le altre vie d'acqua del Lazio antico. Settimo incontro di studio del comitato per l'archeologia laziale, Rome, I 57-97.

Cornell, T. J. I995: The Beginnings of Rome, London.

Cressedi, G. I949-5I: 'I porti fluviali in Roma Antica', Rendiconti della Pontificia Accademia Romana di Archeologia 25-26, 53-65.

Cressedi, G. I984: 'Il Foro Boario e il Velabro', Bullettino della Commissione Archeologica Comunale di Roma 89, 249-96.

Cristofani, M. (ed.) I990: La Grande Roma dei Tarquini, Rome.

Davies, P. J. E. 2017: Architecture and Politics in Republican Rome, Cambridge.

De Santis, A., Mieli, G., Rosa, C., Matteucci, R., Celant, A., Minniti, C., Catalano, P., De Angelis, F., Di Giannantonio, S., Giardino, C. and Giannini, P. 20ıо: 'Le fasi di occupazione nell'area centrale di Roma in età protostorica: nuovi dati dagli scavi nel Foro di Cesare', Scienze dell'Antichità I6, 259-84. 
Diffendale, D. P. 20I7: The Roman Middle Republic at Sant'Omobono, PhD Diss., University of Michigan.

Diffendale, D. P., Brocato, P., Terrenato, N. and Brock, A. L. 2016: 'Sant'Omobono: an interim status quaestionis', Journal of Roman Archaeology 29, 7-42.

Domínguez Pérez, J. C. 2006: 'Estructuras comerciales romanas en el período pre-anibálico', Gerión 24, I79-94.

Dyer, T. H. I857: 'Roma', in W. Smith (ed.), Dictionary of Greek and Roman Geography, Vol. II, Boston, 7I9-855.

Filippi, D. 2005: 'Il velabro e le origini del Foro', Workshop di Archeologia Classica 2, 93-I I6.

Filippi, D. 2020: Il Velabro, Vecchi Scavi e Nuove Letture, Pisa.

Forsythe, G. 2005: A Critical History of Early Rome: From Prehistory to the First Punic War, Berkeley, CA.

Fulminante, F. 20I4: The Urbanisation of Rome and Latium Vetus: From the Bronze Age to the Archaic Era, Cambridge.

Giovannini, A. I985: 'Le sel et la fortune de Rome', Athenaeum 63, 373-86.

Gjerstad, E. I966: Early Rome IV, Lund.

Goiran, J.-P., Salomon, F., Vittori, C., Delile, H., Christiansen, J., Oberlin, C., Boetto, G., Arnaud, P., Mazzini, I., Sadori, L, Poccardi, G. and Pellegrino, A. 20I7: 'High chrono-stratigraphical resolution of the harbour sequence of Ostia: palaeo-depth of the basin, ship draught and dredging', in T. V. Franconi (ed.), Fluvial Landscapes in the Roman World, Portsmouth, RI, 68-84.

Grandazzi, A. 1991: La fondation de Rome, Paris.

Heurgon, J. I973: 'Les graffites d'Aleria', in J. Jehasse and L. Jehasse (eds), La nécropole préromaine d'Aléria, Paris, 547-76.

Holland, L. A. I96r: Janus and the Bridge, Rome.

Holloway, R. R. I994: Archaeology of Early Rome and Latium, London.

Hopkins, J. N. 2007: 'The Cloaca Maxima and the monumental manipulation of water in Archaic Rome', in K. W. Rinne (ed.), The Waters of Rome, Charlottesville, VA, I-I 5.

Hopkins, J. N. 20I2: 'The 'sacred sewer': tradition and religion in the Cloaca Maxima', in M. Bradley (ed.), Rome, Pollution, and Propriety, Cambridge, 8I-IO2.

Hopkins, J. N. 20I6: The Genesis of Roman Architecture, New Haven, CT.

Houston, G. W. I988: 'Ports in perspective: some comparative materials on Roman merchant ships and ports', American Journal of Archaeology 92, 553-64.

Hülsen, C. I 896: 'Il Foro Boario e le sue adiacenze nell'antichità', Atti della Pontificia Accademia Romana di Archeologia 2, 23 I-75.

Isayev, E. 2017: Migration, Mobility and Place in Ancient Italy, Cambridge.

Keay, S. J. (ed.) 20I 2: Rome, Portus and the Mediterranean, London.

Le Gall, J. I953: Le Tibre, fleuve de Rome dans l'antiquité, Paris.

Lomas, K. 20I 8: The Rise of Rome: From the Iron Age to the Punic Wars, Cambridge, MA.

Lugli, F. and Rosa, C. 2003: 'Prime evidenze di opere di terrazzamento del Capitolium nell'età del Bronzo recente', Bullettino della Commissione Archeologica Comunale di Roma I02, 28 I-90.

Lulof, P. S. and Smith, C. J. (eds) 20I7: The Age of Tarquinius Superbus: Central Italy in the Late 6th Century, Leuven.

Marra, F., Motta, L., Brock, A. L., Macrì, P., Florindo, F., Sadori, L. and Terrenato, N. 20ı 8: 'Rome in its setting. Post-glacial aggradation history of the Tiber River alluvial deposits and tectonic origin of the Tiber Island', PLOS ONE I3 3 (3), eor 94838.

Mercuri, A. M. and Sadori, L. 20I 2: 'Climate changes and human settlements since the Bronze age period in central Italy', Rendiconti online della società geologica Italiana I 8, 32-4.

Miano, D. 20I 8: Fortuna: Deity and Concept in Archaic and Republican Italy, Oxford.

Mogetta, M. 201 5: 'A new date for concrete in Rome', Journal of Roman Studies I05, I-40.

Momigliano, A. I990: 'The origins of Rome', in Walbank, Astin, Frederiksen and Ogilvie I990, $52-\mathrm{II} 2$.

Mommsen, T. I 854-6: Römische Geschichte, Leipzig.

Muzzioli, M. P. 2009: 'Le piene del Tevere e la sistemazione delle «ripae» a Roma. Il contributo della pianta di via Anicia', in E. Hermon (ed.), Changements climatiques dans une perspective historique et systémique des interactions société-environnement naturel dans l'empire romain, Naples, 389-407. 
Niebuhr, B. G. I 828: The History of Rome, Vol. I, translated by J. C. Hare and C. Thirlwall, Cambridge.

Piganiol, A. I909: 'Les origines du Forum Boarium', Mélanges d'archéologie et d'histoire 29, 103-44.

Pisani Sartorio, G. (ed.) I989: Il viver quotidiano in Roma arcaica: materiali dagli scavi del tempio arcaico nell'area sacra di S. Omobono, Rome.

Platner, S. B. and Ashby, T. I929: A Topographical Dictionary of Ancient Rome, London.

Quilici, L. I995: 'Il plastico di Roma arcaica al Museo della Civiltà Romana', Ocnus 3, I43-55.

Rakob, F. and Heilmeyer, W.-D. I973: Der Rundtempel am Tiber in Rom, Mainz.

Richardson, L. 1992: A New Topographical Dictionary of Ancient Rome, Baltimore, MD.

Ruggiero, I. I99I-92: 'Ricerche sul tempio di Portuno nel Foro Boario: per una rilettura del monumento', Bullettino della Commissione Archeologica Comunale di Roma 94, 253-86.

Secci, D. A. 20I3: 'Hercules, Cacus, and Evander's Myth-Making in Aeneid 8', Harvard Studies in Classical Philology 107, 195-227.

Smith, C. J. 1996: Early Rome and Latium. Economy and Society c. 1000-500 B.C., Oxford.

Stoddart, S., Woodbridge, J., Palmisano, A., Mercuri, A. M., Mensing, S. A., Colombaroli, D., Sadori, L., Magri, D., Di Rita, F., Giardini, M., Mariotti Lippi, M., Montanari, C., Bellini, C., Florenzano, A., Torri, P., Bevan, A., Shennan, S., Fyfe, R. and Roberts, C. N. 2019: 'Tyrrhenian central Italy: Holocene population and landscape ecology', Holocene 29, 76I-75.

Terrenato, N., Brocato, P., Caruso, G., Ramieri, A. M., Becker, H. W., Cangemi, I., Mantiloni, G. and Regoli, C. 20I 2: 'The S. Omobono Sanctuary in Rome: Assessing eighty years of fieldwork and exploring perspectives for the future', Internet Archaeology $3 \mathrm{I}$.

Torelli, M. I990: 'Archaic Rome Between Latium and Etruria', in Walbank, Astin, Frederiksen and Ogilvie I990, 30-5I.

Torelli, M. 2006: 'Ara Maxima Herculis: storia di un monumento', Mélanges de l'École française de Rome. Antiquité I I 8, 573-620.

Tuck, S. L. 20I3: 'Ports', in J. DeRose Evans (ed.), A Companion to the Archaeology of the Roman Republic, Oxford, 323-34.

Votruba, G. F. 20I7: 'Did vessels beach in the ancient Mediterranean? An assessment of the textual and visual evidence', The Mariner's Mirror 103, 7-29.

Walbank, F. W., Astin, A. E., Frederiksen, M. W. and Ogilvie R. M. (eds) r990: The Cambridge Ancient History VII Part 2: The Rise of Rome to 220 BC, 2nd edn, Cambridge.

Wiseman, T. P. I996: 'What do we know about early Rome?', Journal of Roman Archaeology 9, 3IO-I 5 .

Wiseman, T. P. 2008: Unwritten Rome, Exeter.

Ziółkowski, A. I992: The Temples of Mid-Republican Rome and their Historical and Topographical Context, Rome.

Ziółkowski, A. 2019: From Roma quadrata to la grande Roma dei Tarquini: A Study of the Literary Tradition on Rome's Territorial Growth under the Kings, Stuttgart. 